Int. J. Dev. Biol. 62: 153-166 (2018)

https://doi.org/10.1387/ijdb.170319cs

\title{
Sex determination and gonadal sex differentiation in the chicken model
}

\author{
CLAIRE E. HIRST, ANDREW T. MAJOR and CRAIG A. SMITH* \\ Monash Biomedicine Discovery Institute and Department of Anatomy and Developmental Biology, \\ Monash University, Clayton, Victoria, Australia
}

\begin{abstract}
Our understanding of avian sex determination and gonadal development is derived primarily from the studies in the chicken. Analysis of gynandromorphic chickens and experimental chimeras indicate that sexual phenotype is at least partly cell autonomous in the chicken, with sexually dimorphic gene expression occurring in different tissue and different stages. Gonadal sex differentiation is just one of the many manifestations of sexual phenotype. As in other birds, the chicken has a ZZ male: ZW female sex chromosome system, in which the male is the homogametic sex. Most evidence favours a Z chromosome dosage mechanism underling chicken sex determination, with little evidence of a role for the $\mathbf{W}$ chromosome. Indeed, the $\mathbf{W}$ appears to harbour a small number of genes that are un-related to sexual development, but have been retained because they are dosage sensitive factors. As global Z dosage compensation is absent in birds, Z-linked genes may direct sexual development in different tissues (males having on average 1.5 to 2 times the expression level of females). In the embryonic gonads, the Z-linked DMRT1 gene plays a key role in testis development. Beyond the gonads, other combinations of Z-linked genes may govern sexual development, together with a role for sex steroid hormones. Gonadal DMRT1 is thought to activate other players in testis development, namely $S O X 9$ and $A M H$, and the recently identified HEMGN gene. DMRT1 also represses ovarian pathway genes, such as FOXL2 and CYP19A1. A lower level of DMRT1 expression in the female gonads is compatible with activation of the ovarian pathway. Some outstanding questions include how the key testis and ovary genes, DMRT1 and FOXL2, are regulated. In addition, confirmation of the central role of these genes awaits genome editing approaches.
\end{abstract}

KEY WORDS: chicken, gonad, sex determination, sexual differentiation, embryonic

\section{Introduction}

The chicken (Gallus gallus domesticus) is a scientifically and commercially important species. It has been used as an accessible model organism for researchers for over 100 years and it is a major food source for the human population (Doran et al., 2016). The global poultry industry currently seeks methods of modulating sexual development in chickens. In the egg industry, in particular, only female birds are required and males are usually culled, a significant animal welfare and economic issue (Doran et al., 2017). The ability to generate monosex lines of birds (e.g., all female) would be of significant value to the poultry industry. Efforts to modulate sex in chickens depends upon a sound knowledge of normal sex determination and sexual development. Recent years have seen some major advances in our understanding of chicken sex determination (Schmid et al., 2015). This review will describe the current knowledge around sex determination in the chicken, with particular emphasis of sexual differentiation of the gonads, and the role played by key transcription factors, signalling molecules and hormones. Three major advances have been made in the past 10 years; (1) the finding that sexual phenotype is at least partly cell autonomous in chicken, in the gonads and throughout the embryo (Clinton et al., 2012, Zhao et al., 2010) (2) definition of the gene content of the curious W sex chromosome and (3) the discovery of the likely master genetic switch for testis development, DMRT1 (doublesex and mab-3-related transcription factor 1) (Lambeth et al., 2014, Major and Smith,

Abbreviations used in this paper: DMRT1, doublesex and mab-3-related transcription factor 1; HH, Hamburger and Hamilton stage; PGC, primordial germ cell.

*Address correspondence to: Craig A. Smith. 19 Innovation Walk, Wellington Road, Monash University, Clayton, Victoria, Australia 3800. Tel: +61 399050203.
E-mail: Craig.Smith@ @monash.edu - (D) http://orcid.org/0000-0002-1670-5545 
2016, Raymond et al., 1999, Shan et al., 2000, Smith et al., 1999a, Smith et al., 2009a).

\section{Sex determination and sexual development}

Fundamentally, sex is determined at fertilization by the differential inheritance of the sex chromosomes. In chicken and other birds, male is ZZ and female is ZW. Avian sex chromosomes are not homologous to those of mammals, having evolved from a different pair of autosomes in reptilian ancestors (Graves, 2016, Warren et al., 2017). The traditional model of chicken sex determination follows that espoused for other vertebrates (Jost et al., 1973); genes on one or both of the sex chromosomes direct differentiation of the embryonic gonads into either ovary (ZW) or testis (ZZ), and steroid hormones secreted from the gonads then feminise or masculinise other parts of the body. However, this "gonad-centric" view of sex looks increasingly antiquated, as several lines of evidence indicate that direct genetic effects can play a major cell autonomous role in sexual development, both in birds and other organisms (Agate et al., 2003, Arnold, 1996, Arnold, 2012, Arnold et al., 2013). It is now no longer appropriate to refer to gonadal sex differentiation in birds or mammals as "sex determination." Gonadogenesis is properly viewed as one of many manifestations of "sexual differentiation".

Sexual differentiation involves both direct cell autonomous and indirect hormonal mechanisms, and aspects of sexual differentiation in the embryo can precede those in the gonads. In birds, several lines of evidence support the notion of at least partial cell autonomous sexual development. Zhao and colleagues reported three rare gynandromorphic chickens that are bilateral sex chime-

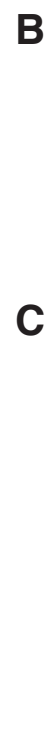

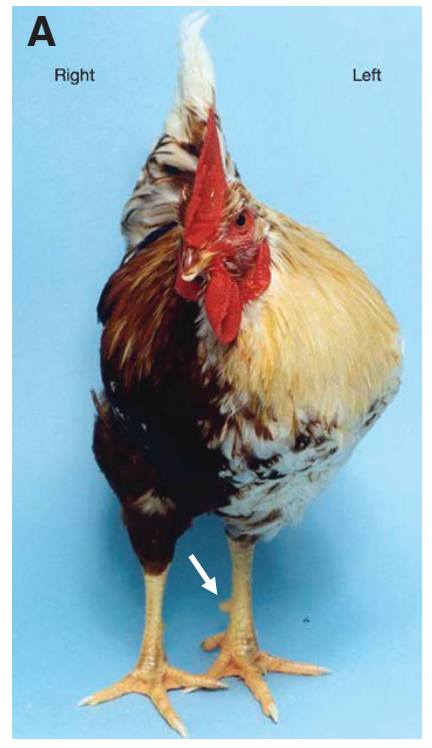

B
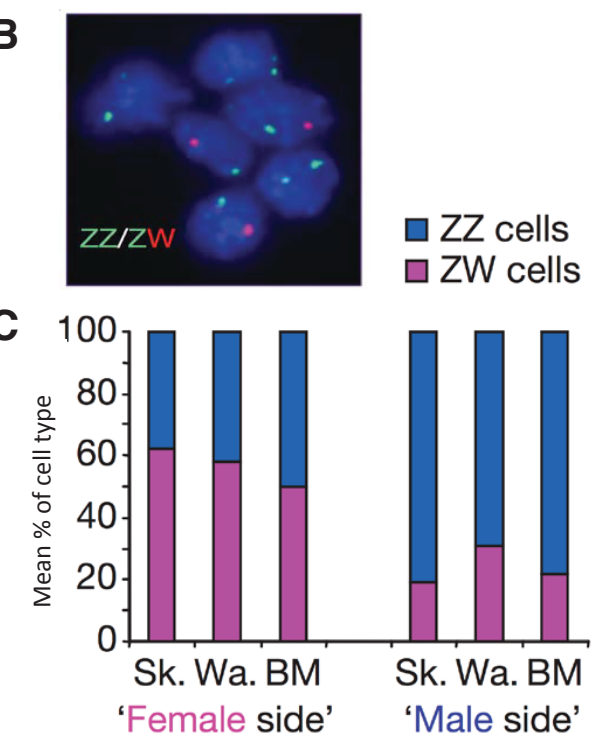

Fig. 1. Distribution of male and female cells in a gynandromorphic chicken. (A) $A$ naturally occurring gynandromorphic chicken, with sex-linked feather colouring. The right side is female, with brown feathers, smaller leg, wattle and breast muscle. The left side is male, with pale feathering and larger wattle, breast muscle and a spur in a larger leg (white arrow). (B) FISH analysis of sex chromosomes in gynandromorph blood cells. Interphase nuclei, showing a mix of both ZZ and ZW cells. (C) Mean relative proportions of ZZ and ZW cells in tissues from "male" and "female" sides of gynandromorph birds. Sk, skin; Wa, wattle; BM, breast muscle. Reproduced from Zhao et al., (2010), with permissions from Nature Publishing Group. ras - male on one side of the body and female on the other (Fig. 1) (Zhao et al., 2010). Such unusual birds are unlikely to derive from a hormonal mechanism, as hormones would flow to both sides of the body. They are also unlikely to derive from a mutation in a ZW or ZZ embryo at the two-cell stage of development as the birds had (Foth ZZ and ZW cells (Fig. 1B). The "male" side was predominantly C). The authors termed this phenomenon CASI (Cell Autonomous Sex Identity) and have noted that such a phenomenon has been also reported in other organisms (Clinton et al., 2012). These gynmorphic birds support the notion that cells in the body of the effects. Zhao et al., supported this idea by producing cross-sex embryonic chimeras. This was achieved by transplanting female pre-gonadal mesodermal tissue into male hosts and vice versa, prio of markers, the transplanted tissue differentiated into the sex of the donor, not the host (Zhao et al., 2010). This again supported direct cell autonomous sexual development.

These findings are consistent with the finding that sexually dimorphic gene expression in chicken embryos can occur prior to the time of gonadal sex differentiation and hence predate any sexually dimorphic hormonal output (Ayers et al., 2013a, Lin et al., 2010, to that of Zhao et al., Maekawa et al., (2013) switched primordial brains between $Z Z$ and ZW chicken embryos before gonadal sex differentiation (and vice versa) and raised birds to sexual maturity. The transplanted donor brains retain the neuroendocrine features of the donor (Maekawa et al., 2013). This is in agreement with previous data pointing to an intrinsic sexual identity of brain tissues, at least partly independent of gonadal sex hormones (Arnold, 1996, Wade and Arnold, 1996, Wade et al., 1997, Wade et al., 1996). Most recently, our ownlaboratory produced transgenic chicken constitutively expressing the CYP19A1 gene, which synthesises oestrogen and can feminise male gonads, yet hatched birds maintained a predominantly male phenotype (Lambeth et al., 2016b). Taken together, these data indicate that direct genetic factors have a major role in regulating sexual differentiation in the chicken. There is nevertheless a role for gonad derived sex steroid hormones in avian sexual differentiation, both in the gonads and in extragonadal tissues. Oestrogen is essential for chicken ovarian development (see below for more details). Blocking oestrogen synthesis can have a potent masculinising effect upon genetically female birds (Elbrecht and Smith, 1992a, Lambeth et al., 2013, Vaillant et al., 2001), while over-expression of CYP19A1 or the administration of oestrogen can feminise males, albeit transiently (Lambeth et al., 2013, Scheib, 1983). Meanwhile gonadectomy can also alter sexual features such as plumage and behaviour (Lambeth and Smith, 2012, Owens and Short, 1995). Clearly, sexual differentiation in the chicken must have both direct cell autonomous and hormonal input.

In the case of directcell autonomous factors regulating sexual differentiation, different tissues may respond to different combination sof sex-linked factors, that could be either Z- or W-linked. The large chicken Z chromosome 


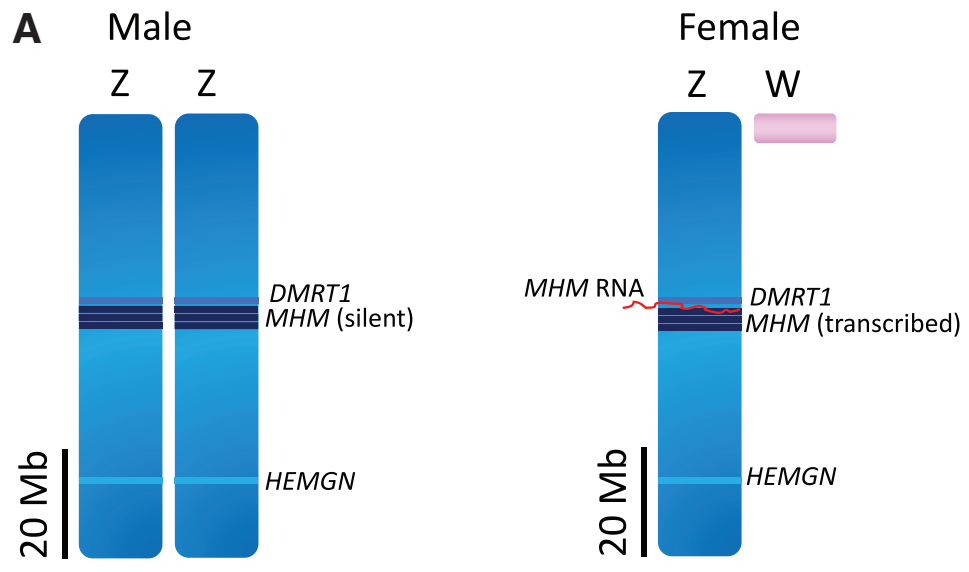

B

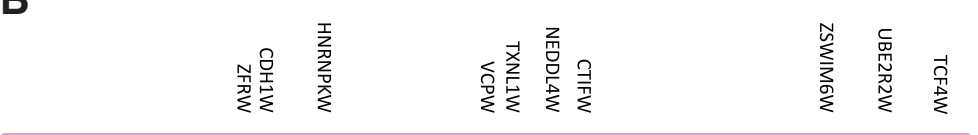

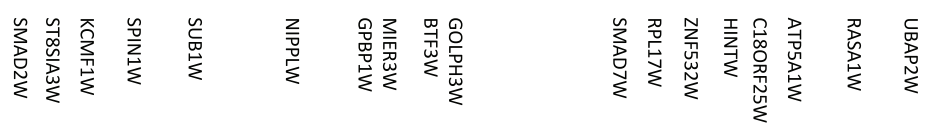

Fig. 2. Schematic view of chicken sex chromosomes and sex determining genes. (A) The large $Z$ chromosome $(82.3 \mathrm{Mb})$ is drawn to scale next to the degenerate $W$ chromosome (7 Mb). Male (ZZ) chickens have two copies of DMRT1 and HEMGN, while the female (ZW) only has one. The MHM locus is transcribed from the single $Z$ in the female and may play a role in local dosage, and epigenetic regulation of DMRT1 in the female. (B) Location and orientation of the 28 protein coding genes that are located on the W chromosome. Modified from Bellott et al., (2017), with permissions from Nature Publishing Group.

harbours over 1000 genes, most of which are "house-keeping" genes unrelated to sex (Schmid et al., 2015). The chicken W sex chromosome is a severely degraded copy of the $Z$ chromosome, with perhaps as few as 28 genes having remained over evolution (Fig. 2B) (Ayers et al., 2013a, Bellott et al., 2017, Mank and Ellegren, 2007, Moghadam et al., 2012). This sets up a dosage inequality of most Z-linked genes between the sexes. In the context of cell autonomous sexual development, it is particularly noteworthy that birds lack a system of global $Z$ chromosome dosage compensation akin to mammalian X inactivation (Arnold et al., 2008, Ellegren, 2011, Ellegren et al., 2007, Itoh et al., 2007, Kuroda et al., 2001, Melamed and Arnold, 2007, Naurin et al., 2012, Wang et al., 2017). In the chicken, Z-linked genes are expressed on average at 1.4 -1.8 times more highly in males (ZZ) compared to females (ZW), across various tissues (Arnold and Itoh, 2011, McQueen and Clinton, 2009, Wright et al., 2012). There is some local equalisation of gene dosage, but this is gene-specific, and involves Z-linked genes that are dosage sensitive and for which a certain dose of expression is critical (Mank and Ellegren, 2009, McQueen and Clinton, 2009, Zimmer et al., 2016). The overall Z gene dosage inequality between the sexes exists in gonadal and non-gonadal cells prior to gonadal sex differentiation into ovaries or testes (Ellegren et al., 2007) and so could provide a mechanism for cell autonomous sexual development. Alternatively, W-linked genes could be a source of sexual dimorphic gene expression, but recent studies show that the few genes present on the chicken $\mathrm{W}$ chromosome are very highly homologous to partners on the Z (so-called "gametologues") and are expressed at similar levels (Ayers et al., 2013a). These W genes are likely to be dosage sensitive factors that have been retained on the otherwise degenerate chicken $W$ to match expression between females and males (Bellott et al., 2017).

One region of the chicken $Z$ sex chromosome has a concentration of genes that do show dosage compensation, and these genes lie adjacent to a Z-linked locus called MHM (Male HyperMethylated). This 2.2kb repeat sequence is hypermethylated and silent in male cells (ZZ) but is hypomethylated on open chromatin and transcribed into a long non-coding RNA in female cells (ZW) (Fig. 2A) (Teranishi et al., 2001). Intriguingly, $M H M$ IncRNA coats the female $Z$ chromosome in close proximity to a subset of genes that are compensated (up-regulated in females). MHM is ostensibly similar to XIST in mammals, which is a non-coding RNA that mediates $\mathrm{X}$ inactivation (Briggs and Reijo Pera, 2014). However, in the case of $M H M$, the neighbouring female genes are up-regulated, and the associated histone H4K16 is hyperacetylated, an epigenetic mark of active gene up-regulation (Bisoni et al., 2005). MHM may thus play a role in local dosage compensation, elevating Z-linked gene expression in females to levels comparable to that of males. However, the sequence although it appears to be limited to Galliform birds (such as chickens and turkey), and not all avians (Itoh et al., 2010, Wright et al., 2015). The likely avian testis-determinant DMRT1 (see below), is located very close to the site of $M H M$ binding, and indeed both are located on the same loop in lampbrush preparations of the Z chromosome (Teranishi et al., 2001). This had led to the suggestion that $M H M$ could play a role in gonadal sex differentiation by contributing to epigenetic repression of DMRT1 expression female gonadal cells (Caetano et al., 2014, Roeszler et al., 2012, Teranishi et al., 2001, Yang et al., 2016, Yang et al., 2011, Yang et al., 2010). Interestingly, Itoh and colleagues reported an asymmetric effect of the demethylating agent 5-aza-cytidine on MHM expression from the two $\mathrm{Z}$ chromosomes of male cells, with one expressing more than the other (Itoh et al., 2011). This suggests an inequality of the MHM methylation status between the two Z sex chromosomes, but the functional significance of this observation is unclear. In the chicken, $M H M$ expression begins at the time of fertilization in ZW zygote. The role of $M H M$ may be linked to either local dosage compensation or sex determination, or both. Global over-expression of $M H M$ causes developmental abnormalities in chicken embryos that are not sex-specific, and an apparent reduction in DMRT1 gonadal expression (Roeszler et al., 2012). The exact function of this sequence could be further clarified by knockdown or knockout (CRISPR/Cas9) approaches (Woodcock et al., 2017). If it indeed plays an essential role in local dosage compensation, one might predict that loss of $M H M$ expression would cause lethality of female embryos. If it has a role in repressing DMRT1 expression in ZW cells, loss of MHM could lead to elevated DMRT1 and testicular development.

\section{Chicken sex chromosomes}

The $Z$ and/or $W$ sex chromosomes of the chicken must harbor one or more sex-determining genes. The $82.3 \mathrm{Mb}$ chicken $\mathrm{Z}$ chromosome is large and contains over 1000 genes, many with 
"house-keeping" functions (Handley et al., 2004). There are 884 protein-coding sequences and some 348 non-coding genes (microRNAs and long non-coding sequences) (Bellott et al., 2010, Ellegren, 2011). Due to the absence of global dosage compensation and hence potential expression inequality between $\mathrm{ZZ}$ and $\mathrm{ZW}$ cells, any of these genes could serve a sex-determining role in a particular tissue (Ayers et al., 2013b). The Z sex chromosome has been strongly "masculinised" over evolution (enriched for male-biased gene expression) (Kaiser and Ellegren, 2006, Mank and Ellegren, 2009, Storchova and Divina, 2006, Wright et al., 2012) and there has also been an accumulation of genes related to sex and reproduction on the Z (Ellegren, 2011, Mank et al., 2007, Morkovsky et al., 2010, Naurin et al., 2012). This includes two important genes expressed in the developing testis, DMRT1 and HEMGN(discussed below). These observations suggest that it is the $\mathrm{Z}$, rather than the $\mathrm{W}$, that plays a central role in chicken sex determination. Indeed, the $\mathrm{W}$ chromosome lacks an obvious candidate gene that could be sex-determining. As noted above, the chicken $\mathrm{W}$ sex chromosome is a smaller degraded version of the Z, with perhaps as few as 28 bona fide genes. (Fig. 2B). At $7 \mathrm{Mb}$, the chicken $\mathrm{W}$ chromosome is $6 \%$ of the size of the $Z$ chromosome. Most of the $\mathrm{W}$ chromosome is heterochromatic, with a smaller euchromatic region harbouring protein-coding genes. The most recent build of the chicken $\mathrm{W}$ chromosome (galGal5) annotates 25 protein-coding genes and around 116 non-coding RNAs (Bellott et al., 2017, Warren et al., 2017). In theory, any of these could play a sex-determining role, as for any non-dosage compensated Z-linked genes described above. However, we have previously found that the $27 \mathrm{~W}$-linked genes have partners on the $Z$ sex chromosome to which they are they are highly homologous (over 90\% in most cases) (Ayers et al., 2013a, Warren et al., 2017). In the chicken (and in the collared flycatcher), the combined expression levels of the $\mathrm{Z}$ and $\mathrm{W}$ homologues in females are comparable to the expression levels from the two $Z$ chromosomes in males, and expression occurs broadly across embryonic and/or adult tissues (Ayers et al., 2013a, Smeds et al., 2015) (Fig. 3). These features make these genes unlikely sex determinants (Bellott et al., 2017).

It has been proposed that the small number of single copy dosage sensitive genes retained on the chicken $\mathrm{W}$ have important roles in development. Indeed, these genes have predicted UniProt annotations associated with fundamental cellular process, such as transcription, translation, protein degradation, chromatin modification and signal transduction (Bellott et al., 2017). Only one W-linked gene is significantly divergent in sequence from its $Z$ homologue, HINTW (Hori et al., 2000), and this gene has been amplified into a multicopy family containing approximately 40 copies on chicken W chromosome (Bellott et al., 2017). HINTW is conserved among volant (flying) birds and is expressed widely in chicken embryos (Hori et al., 2000, O'Neill et al., 2000). These features have made HINTWa candidate female or ovary determinant. The Z homologue encodes a histidine triad nucleotide binding protein of the HIT family, however, HINTW is aberrant in that it specifically lacks the key catalytic domain required for the protein to function (Brenner, 2002, Moriyama et al., 2006, Parks et al., 2004). As such it has been suggested that HINTW could act as a dominant negative in avian sex determination, blocking the male-promoting function of HINTZ (Ayers et al., 2013a, Bellott et al., 2017, Brenner et al., 1999, Moghadam et al., 2012, Pace and Brenner, 2003). However, despite these findings, over-expression of HINTW does not induce feminisation of ZZ chicken embryos (Smith et al., 2009b). However, recent evidence has shown that experimental female to male sex reversal using the aromatase inhibitor fadrozole, does not affect the high level of HINTW RNA in chicken gonads. Furthermore, antibodies generated and validated against chicken HINTW fail to detect endogenous HINTW protein in chicken gonads. Additionally, while HINTWRNA can be detected in chicken and zebra finch gonads, no homologue appears to be present in the emu (Hirst et al., 2017b). Taken together, this data undermines the role for HINTW as the $\mathrm{W}$-linked female sex determining gene, and reinforces a role for gene dosage of Z-linked DMRT1 as the mechanism for sex-determination in birds (discussed below).
Fig. 3. Expression levels of $W / Z$ gametologue pairs in the chicken gonad. Expression of W-linked genes (red) compared to their Z-linked gametologues (blue) in chicken gonads. The total combined expression of gametologue pairs is shown for females (left bar of pair) and males (right bar of pair). The shaded data (inset) are shown on an adjusted FPKM scale. Genes with significantly differentexpression between the sexes are identified (* $P<0.01$ ). Reproduced from Ayers et al., (2013a), with permissions under CC-BY-4.0; the license terms can be found at: (https://creativecommons. org/licenses/by/4.0/legalcode).

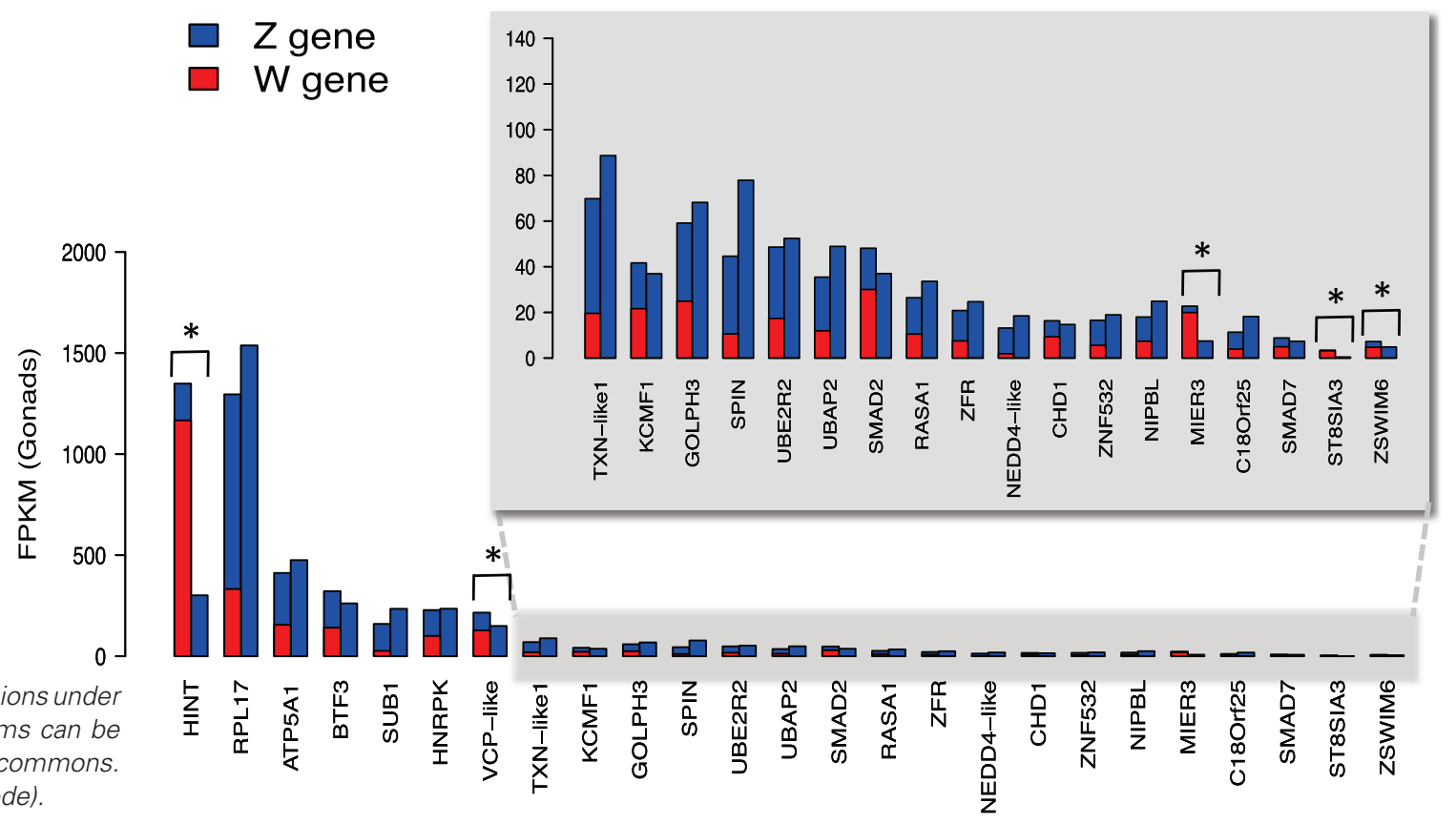


Fig. 4. Expression of Rspondin 1, WNT4 and $\beta$-catenin in the chicken embryonic ovary. (A) Detection of RSPO1 protein in embryonic chicken gonads, using a chicken RSPO1specific antibody raised in rabbits (green). RSPO1 is expressed in the developing ovarian cortex at E6.5 and E12.5, but is lowly expressed in the testis. Fibronectin (red) delimits the medulla from the cortex. (B) $\beta$-catenin (green) andWNT4 (red) expression in developing chicken gonads. Both proteins are highly expressed in the ovarian cortex from earlygonadal stages, but not expressed in the testis. WNT4 is also upregulated in the inner medulla at later stages. Reproduced from Ayers et al., (2013b), with permissions from S. Karger AG, Basel.

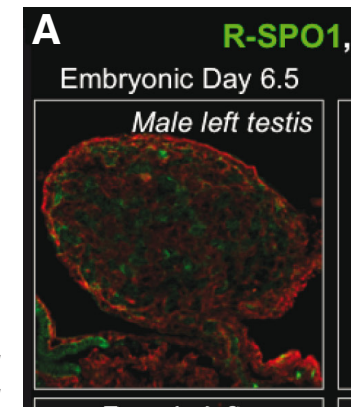

1, Fibronectin

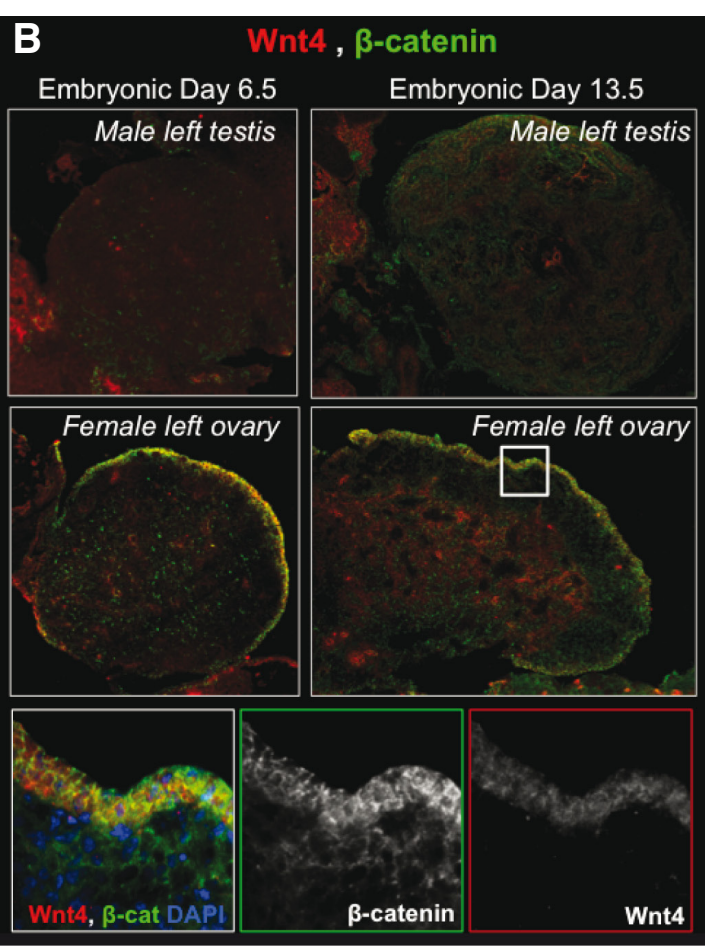

\section{Embryonic development of the gonads}

The embryonic urogenital system arises from the intermediate mesoderm at approximately day $3(\mathrm{HH} 18)$ of embryonic development, and is marked by the thickening of the coelomic epithelium ventral to the mesonephros. At the same time, primordial germ cells (PGCs) migrate from the germinal crescent into the gonads via the blood stream (Ginsburg and Eyal-Giladi, 1987). Prior to differentiation at E4.5 (HH26), the undifferentiated gonad consists of a thin outer cortical layer overlying an inner medulla.

Several genes have been shown to be important for these initial stages of gonad differentiation. Two of the earliest genes expressed are Steroidogenic Factor-1 (SF1) and GATA4, reviewed in Piprek et al., (2016). GATA4 is expressed in the bipotential gonad in chicken in both sexes at $\mathrm{E} 4$ (HH24) (Oreal et al., 2002), and it is also expressed in the earliest stages of gonad differentiation in mice (Viger et al., 1998). Conditional mutant mice lacking Gata4 fail to form gonads, as there is no thickening of the coelomic epithelium to form the genital ridges (Hu et al., 2013). SF1 is not expressed in the coelomic epithelium of these mice suggesting that GATA4 is upstream of SF1 in initiating the formation of the gonadal primordium (Hu et al., 2013).

Sf1 is initially expressed in the undifferentiated gonads of both male and female mice, and its expression is maintained during testis differentiation but is down-regulated during ovarian differentiation (Ikeda et al., 1994). Consistent with this early expression, null mice lacking Sf1 fail to develop gonads indicating that Sf1 is essential for the formation of the gonadal primordium in both sexes (Luo et al., 1994). Chicken SF1 is also observed in both sexes prior to gonadal differentiation at $\mathrm{E} 5.5(\mathrm{HH} 28)$, but dissimilar to that seen in the mouse, SF1 expression is then up-regulated in developing ovaries after the onset of differentiation (E7.5 HH32) (Smith et al., 1999b, Smith et al., 1999c). This suggests a conserved role for SF1 in early gonad development across vertebrates, but suggests that later in development the role of SF1 in birds and mammals varies.

The differentiation of the bipotential gonad into either a testis or ovary occurs at approximately E6-6.5 (HH29-HH30) of chicken development. In males (ZZ), the cortex of the developing testis remains as a thin epithelial layer, while the gonadal medulla differentiates in seminiferous cords, which enclose the pre-Sertoli cells and PGCs. The pre-Sertoli cells produce anti-Müllerian hormone $(\mathrm{AMH})$, which contributes to the regression of Müllerian ducts (which are the embryonic oviducts), and subsequently the testosteroneproducing Leydig cells differentiate and reside in the mesenchyme outside of the seminiferous cords. In the male, PGCs become enclosed within the developing seminiferous cords and undergo mitotic arrest, entering meiosis only after hatching.

The differentiation of the ovary is characterised by the thickening of the outer cortex and the accumulation of PGCs within it (Carlon and Stahl, 1985). However, this process is asymmetrical as only the cortex of the left gonad proliferates while the right gonad regresses. This asymmetry is mediated by expression of the transcription factor PITX2 in the left gonad specifically, which regulates expression of the oestrogen receptor- $\alpha$ and directs cell proliferation and differentiation of both somatic cells and PGCs within the left gonad (Guioli and Lovell-Badge, 2007, Ishimaru et al., 2008, Rodriguez-Leon et al., 2008). PGCs in the left medulla and right gonad, however, do not undergo meiosis due to the lack of retinoic acid (Smith et al., 2008a), These cells were originally thought to undergo apoptosis (Ukeshima, 1996), however, more recent analysis of PGCs in the right gonad and left medullar indicate that they arrest in meiosis and do not undergo apoptosis until after hatching (de Melo Bernardo et al., 2015).

The thickened cortex of the left gonad contains both somatic cells as well as proliferating PGCs. From E9 (HH35) these PGCs begin to undergo folliculogenesis via synchronous rounds of mitosis and 
meiosis to form germ cell nests. The granulosa and thecal cells that enclose the germ cells are derived from somatic cells from either the cortex or from medullary cells that migrate from just beneath the cortex. Development of the functional left ovary is completed after hatching with the formation of primordial follicles that are arrested in the diplotene phase of prophase I. In the underlying the cortex of both the left and right gonads, the medullary cords become vacuolated and form structures referred to as lacunae.

\section{Molecular mechanisms underlying female gonad differentiation}

Two developmental pathways are thought to act in parallel to determine ovarian development; the first is the FOXL2/Aromatase/ Oestrogen pathway. Oestrogen is an absolute requirement for ovarian development as it essential for the development of the ovaries (Elbrecht and Smith, 1992b, Vaillant et al., 2001), and for the acquisition of secondary sexual characteristics in the adult female bird. Early studies describing the effect of exogenously applied hormones found that treatment of male (ZZ) birds with oestrogen, prior to gonadal differentiation, results in the transient feminization of the male left gonad and the formation an ovary or ovo-testis, while treatment of female $(\mathrm{ZW})$ birds with anti-oestrogens perturbed the development of ovarian structures (Scheib, 1983).

The productions of oestrogens in the developing female (ZW) gonad is determined by the temporal and sex-specific expression of the enzymes involved in steroidogenesis (Bruggeman et al., 2002). The enzymes involved in the upstream steps of the steroidogenesis pathway are expressed in the gonadal medulla of both sexes (Nakabayashi et al., 1998), However, aromatase (CYP19A1) and $17 \beta$-hydroxysteroid dehydrogenase (17 $\beta$-HSD), which are involved in the final steps of the conversion of androgen substrates into the active oestrogens, oestrone and $17 \beta$-oestradiol, are only expressed in the medulla of female (ZW) gonads (Nakabayashi et al., 1998, Nishikimi et al., 2000, Smith et al., 1997, Smith et al., 2005).

The aromatase protein is detected only in the female gonads from E6 ( $\mathrm{HH} 29)$ onwards and its expression increases during gonad differentiation (Smith et al., 1997, Smith et al., 2005). Likewise, $17 \beta$-HSD is expressed in the developing gonads of females, but not males (Nakabayashi et al., 1998, Wajima et al., 1999). As such, oestradiol is never detectable in male gonads and is detected in female gonads from E9 onwards (Imataka et al., 1989). Underscoring the importance of aromatase in the synthesis of oestrogens, aromatase inhibitors, such as fadrozole, induce female-to-male sex reversal in $(Z W)$ females when applied prior to, or during sexual differentiation (Abinawanto et al., 1996, Burke and Henry, 1999, Elbrecht and Smith, 1992b, Hudson et al., 2005, Smith et al., 2003, Vaillant et al., 2001, Wartenberg et al., 1992). Furthermore, the addition of oestrogen rescues fadrozole induced- sex reversal (Elbrecht and Smith, 1992), demonstrating the absolute requirement for oestrogen in the development of the ovary.

In addition to enzymes responsible for oestrogen synthesis, several other genes have been implicated in sex determination in female birds. Numerous studies have indicated that the forkhead transcription factor FOXL2 is an essential player in ovarian development and maintenance in many species including fish, birds and mammals (Loffler et al., 2003, Pisarska et al., 2011, Wang et al., 2004). FOXL2 is expressed in an ovary-specific manner at the time of gonadal sex differentiation in all vertebrates that have been examined. In the chicken, the onset of FOXL2 expression is around $\mathrm{E} 5.7(\mathrm{HH} 28)$, just prior to aromatase and the first signs of ovarian differentiation at E6 (H H29), furthermore FOXL2 and aromatase are co-expressed within cells in the medulla of female gonads (Govoroun et al., 2004). It is therefore thought that FOXL2 controls aromatase
$\mathrm{AMH}$

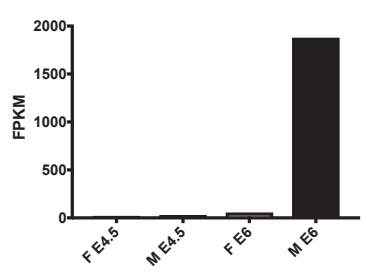

FGF9

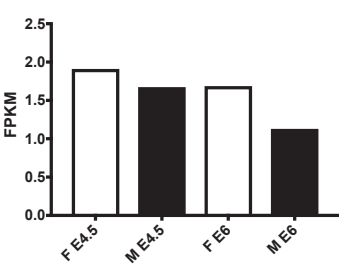

CYP19A1

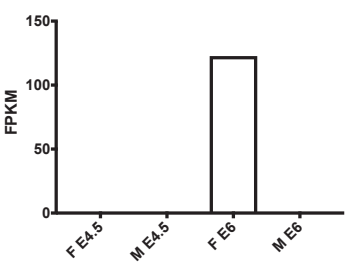

DMRT1

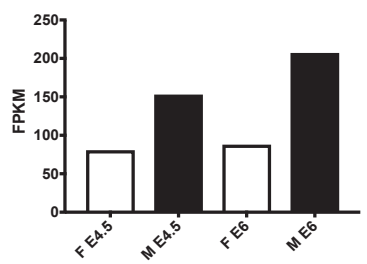

GATA4

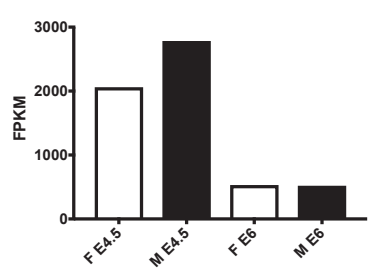

FOXL2

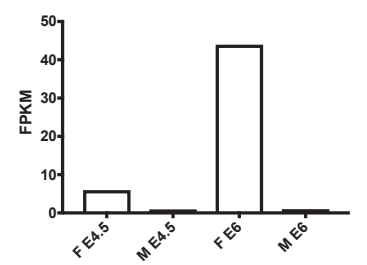

HEMGN

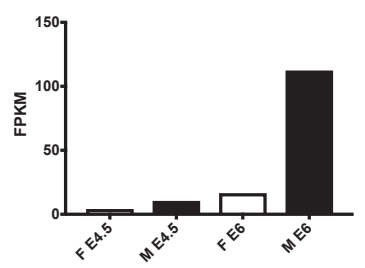

RSPO1

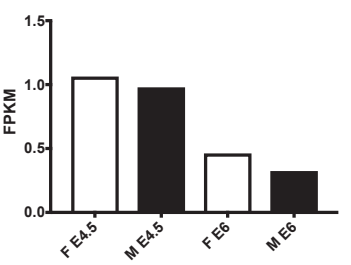

CAPN5

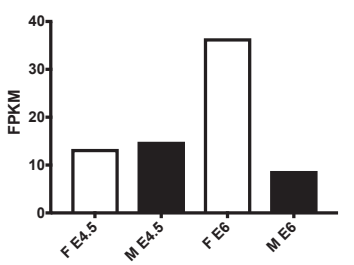

sox9

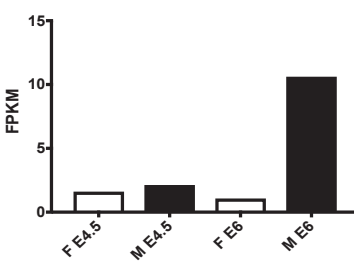

WNT4

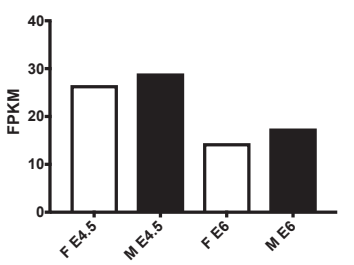

GPR56

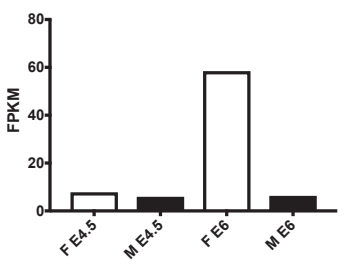

Fig. 5. The expression of known or putative sexdetermining genes in the female and male gonads at E4.5 and E6. RNA-sequencing data demonstrating the male or female biased expression of known and putative sexdetermining genes. Expression is measured in FPKM (Fragments Per Kilobase of exon per Million fragments mapped); data obtained from Ayers et al., (2015b). 
transcription during differentiation of female gonads in the chicken, as has been previously shown for mammals (Bentsi-Barnes et al., 2010, Fleming et al., 2010, Pannetier et al., 2006).

Consistent with this, in vitro analysis has demonstrated that FOXL2 can bind to a highly conserved putative forkhead element in the aromatase promoter to activate transcription (Fleming et al., 2010). While it is not yet known whether FOXL2 can directly control aromatase expression (and therefore oestrogen levels) in vivo, aromatase inhibitors cause a reduction in FOXL2 levels in the female gonads, suggesting a feedback regulatory loop exists between these two genes (Hudson et al., 2005). Whether this is due to the loss of oestrogen synthesis causing a reduction in the expression of FOXL2. Or whether activation of the male sex determining pathway, and expression of male-specific genes such as $S O X 9$, may result if the downregulation of FOXL2. As such the exact mechanism which underlies the interplay between these genes remainsto be elucidated.

In mammals, the canonical WNT4/ $\beta$-catenin signalling pathway has been shown to be a key regulator of ovarian development (Biason-Lauber and Konrad, 2008, Liu et al., 2010). In mice, Wnt4 is initially expressed in the gonad in both sexes but becomes restricted to the female (XX) gonads later in development (Vainio et al., 1999). Loss of Wnt4 in mice causes partial masculinization of the female $(X X)$ gonads, with the loss of the Müllerian duct and concomitant retention of the Wolffian duct, and the ectopic activation of the testosterone synthesis pathway (Vainio et al., 1999). Similarly, loss of $\beta$-catenin in female (XX) gonads also results in masculinization of the ovary with the formation of the testis specific coelomic vessel and androgen expressing cells, and the loss of female germ cells (Liu et al., 2009). Mutations in WNT4 in humans also cause various degrees of female to male sex reversal (Biason-Lauber et al., 2007, Biason-Lauber et al., 2004, Mandel et al., 2008) indicating the importance of this pathway in the development of the ovary. In the chicken, WNT4 is expressed in the bi-potential gonads of both sexes at $\mathrm{E} 4.5$ (HH26), during sexual differentiation from E6.5-E8.5 ( $\mathrm{HH} 29-33)$, the expression is lost from the male ( $\mathrm{ZZ}$ gonad and becomes restricted to the active left ovary of ZW (Smith et al., 2008b).

R-spondin-1 (RSPO1) is a member of a small family of secreted growth factors, that also operate through the canonical Wnt signalling pathway. The RSPO proteins are thought to potentially regulate functions mediated by $\beta$-catenin, by binding the Wnt co-receptor, LRP6, modulating its availability (Binnerts et al., 2007, Wei et al., 2007). Loss of function mutations within human RSPO1 result in complete female to male sex reversal (46, XX males) (Parma et al., 2006) and syndromic true hermaphroditism (Tomaselli et al., 2008). Loss of Rspo1 in mice also results in masculinization of female (XX) gonads due to the absence of WNT4/ $\beta$-catenin signalling, which result in male-like vascularization and steroidogenesis (Chassot et al., 2008). However, it is not clear if what regulates RSPO1 expression in the ovary.

In the chicken RSPO1 is expressed in a sexually dimorphic manner at $\mathrm{E} 4.5(\mathrm{HH} 26)$ at which time its expression is elevated in female $(Z W)$ gonads above the low level observed in male $(Z Z)$ gonads. The mRNA expression level transiently decreases in the female but from E8.5 it is upregulated and becomes strongly female enriched (Smith et al., 2008b). RSPO1 is weakly expressed in the gonadal medulla of both sexes at E6.5 but its expression becomes restricted to the cortex of the left ovary by E12.5 ((Ayers et al., 2013b) Fig. 4A). WNT4 is also expressed within the cortex of the developing ovary at E6.5 and E12.5 along with $\beta$-catenin (Fig. 4B). Therefore,
RSPO1 way interact with WNT4 to activate $\beta$-catenin that is present in these cells.

While both FOXL2 and RSPO1/WNT4 signalling pathways promote ovarian and restrict testis development, it is as yet unclear how these two pathways interact, as mutations in one pathway do not affect the expression of the other (Chassot et al., 2008, Garcia-Ortiz et al., 2009, Ottolenghi et al., 2005). Additionally, these two pathways are expressed in anatomically distinct areas of the developing ovary, as RSPO1 and WNT4/ $\beta$-catenin are expressed in the cortex (Smith et al., 2008b), while FOXL2 and Aromatase are located in the medulla (Govoroun et al., 2004). And while oestrogen is required to maintain RSPO1 expression in the cortex, it is not clear that there is a direct link between these two pathways, as the decrease in RSPO1 may be due to the loss of pre-follicular cells in the cortex rather than a direct effect on RSPO1 (Smith et al., 2008b). Further research into the mechanisms that regulate ovarian differentiation are needed to further unravel the genes that control sex determination in the female.

As it is still not clear what the female determining gene is in chicken, several laboratories have undertaken large scale screens to identify sexually dimorphic genes in the chicken embryo (Ayers et al., 2013a, Ayers et al., 2015b, Carre et al., 2011, Zhang et al., 2010). Two novel female-enriched candidate genes, Calpain-5 (CAPN5) and G-protein coupled receptor 56 (GPR56) were recently identified by RNA sequencing of early chicken gonads (Fig. 5; (Ayers et al., 2015b)).

CAPN5 demonstrated a female biased expression in the gonads of female embryo at stage E6 (HH29; Fig. 5), and was localised to the adrenal gland and the juxta-cortical medulla of female gonads (Ayers et al., 2015b). CAPN5 is an intracellular calcium-dependent cysteine protease that shares homology with the $C$. elegans sex determination gene tra-3 (Dear et al., 1997, Mugita et al., 1997). Polymorphisms of CAPN5 are associated with of polycystic ovary syndrome in women, suggesting that CAPN5 could play a role in ovarian development (Gonzalez et al., 2006). However, Capn5 null mice appear to have normal fertility, although gonadal development has not been examined in detail in these mice (Franz et al., 2004).

GPR56 (also known as ADGRG1 - ADhesion G protein-coupled Receptor G1) also displays a strong female bias in the female gonads at E6 (HH29; Fig. 5), and is localised to cells within the cortex of female but not male gonads (Ayers et al., 2015b). Gpr56 null male mice display reduced fertility due to disruption of the seminiferous tubules, potentially due to loss of basement membrane proteins during testis cord remodelling, which occurs at later stages of testis differentiation in the mouse (Chen et al., 2010). No phenotype has been described for female Gpr56 null mice and the expression of Gpr56 has not been described during mouse ovarian development. Equally, the expression of chicken GPR56 has not been examined in later stages of gonadal differentiation. As such, it is not yet clear whether GPR56 has a conserved role in gonadal development in chicken and mice, and how this gene could regulate differentiation of the gonad at different stage of development.

\section{Z-linked DMRT1 and the molecular mechanisms underlying testis development}

The best candidate avian sex-determining gene under the Z-dosage hypothesis is DMRT1 (doublesex and mab-3-related transcription factor 1). DMRT1 encodes a transcription factor that displays sexually dimorphic expression across multiple mammal, 
bird and reptile species, where its characterised involvement in testis development suggests it is a conserved component of the vertebrate sex-determining pathway (Smith et al., 1999a). DMRT1 contains a DNA-binding motif termed the "DM domain", which is conserved as evolutionarily far back as the worm (Caenorhabditis elegans) gene doublesex and the fly (Drosophila melanogaster) gene mab-3, both know regulators of male sexual development in their respective species (Matson and Zarkower, 2012, Raymond et al., 2000, Raymond et al., 1998). There are many examples of DMRT1 and its orthologues being involved in in sex determination and testis differentiation across multiple vertebrate species. In the Medaka fish (Oryzias latipes) the master sex determinant is a duplicated copy of DMRT1, termed DMY (or DMRT1BY) because it has translocated onto the $\mathrm{Y}$ chromosome (Matsuda et al., 2002, Nanda et al., 2002). Experimentally induced over expression of $D M Y$ induces male development in genetically female (XX) fish (Matsuda et al., 2007), while two naturally occurring mutants that result in truncated or reduced $D M Y$ expression cause perturbation of male development in genetically male (XY) fish (Matsuda et al., 2002). More recently, in Zebrafish (Danio rerio), DMRT1 has been shown to be necessary for testis development (Webster et al., 2017). In the frog (Xenopus laevis), a W-linked dominant negative variant of DMRT1 (DM-W), which lacks the transactivation domain is the likely sex (ovary/female) determining gene (Okada et al., 2009, Yoshimoto et al., 2010, Yoshimoto et al., 2008). Overexpression of DM-W is able to activate the female pathway in ZZ (genetically male) transgenic tadpoles, antagonising the male pathway and autosomal DMRT1 (Yoshimoto et al., 2008). In genetically female (ZW) tadpoles, knockdown of DM-W allows autosomal DMRT1 function and leads to female-to-male sex reversal (Yoshimoto et al., 2010). DMRT1 has also been demonstrated to be both necessary and sufficient to induce male development in two different species of turtles, one that has temperature sex determination (Trachemys scripta, Ge et al., (2017)) while the other has genetic sex determination (Pelodiscus sinensis, Sun et al., 2017).

In the mouse embryo autosomal

B
DMRT1 expression is restricted to the Sertoli cell linage and germ cells of the developing testis with lower levels present in the developing ovary, concordant with its essential role in post-natal mammalian testis development and function (Matson and Zarkower, 2012, Raymond et al., 1999). Notably, DMRT1 appears to be dis-
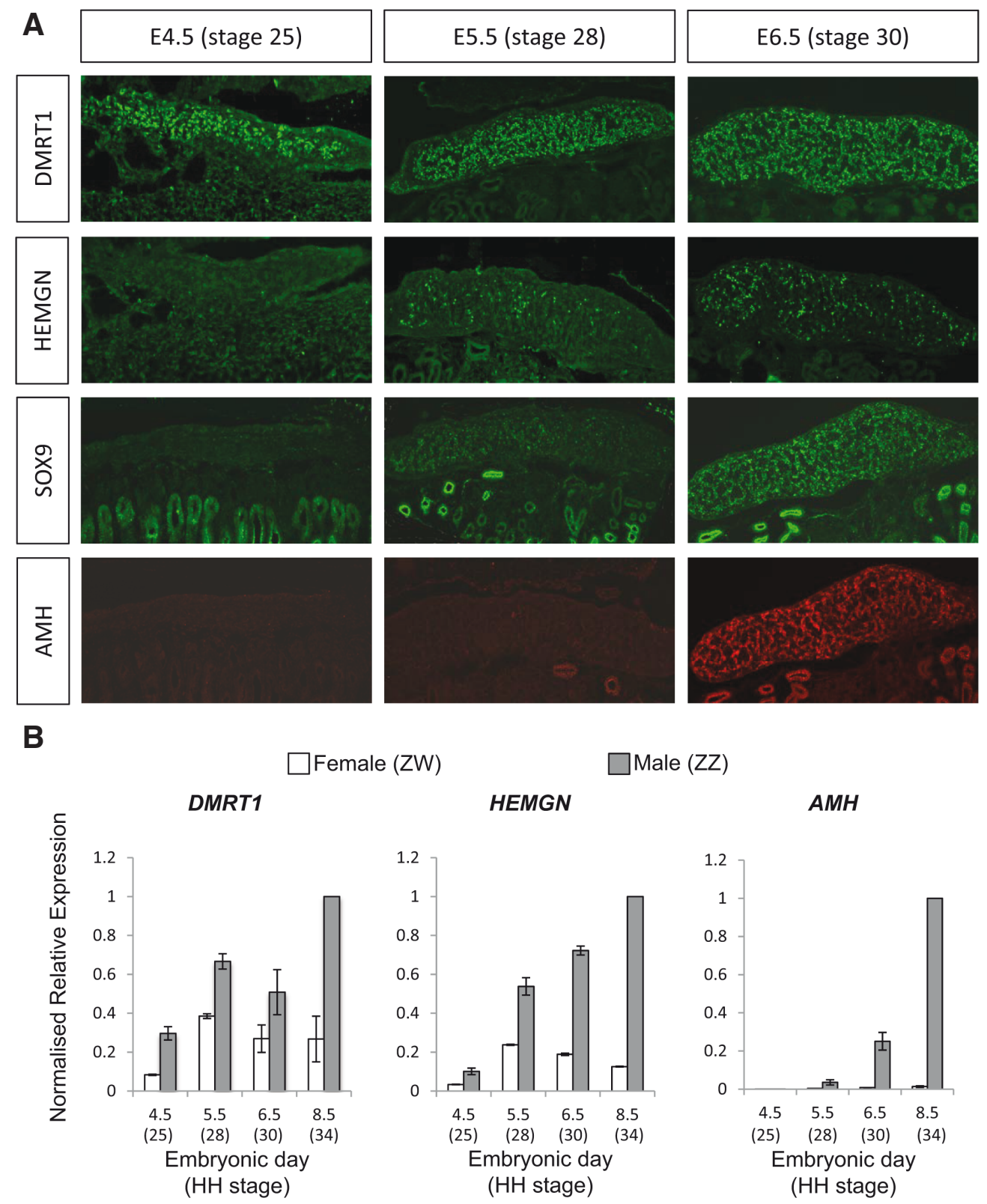

Female $(Z W)$

Male (ZZ)
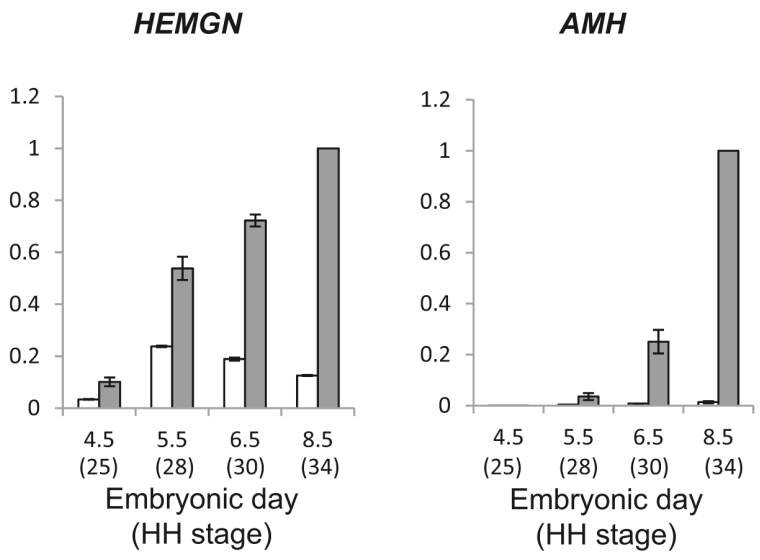

Fig. 6. Chronology of key testis development genes, analysed across several critical stages of chicken sexual differentiation. (A) Immunofluorescent staining of DMRT1 (green), HEMGN (green), SOX9 (green) and AMH (red) expression in E4.5 (HH25), E5.5 (HH28) and E.6.5 (HH30) male embryonic gonads. DMRT1 expression shows robust expression from E4.5 (HH25) onwards. Both HEMGN and SOX9 were expressed from E5.5 (HH28) onwards, and AMH expression was detectable at E6.5 (HH30), SOX and AMH were costains on the same sections. (B) Quantitative RT-PCR analysis comparing expression of DMRT1, HEMGN and AMH mRNA in female and male gonads across stages of embryonic development. All transcripts measured were expressed dimorphically with higher levels in the male tissues for each. DMRT1 is expressed in a male-biased fashion from E4.5 onwards. HEMGN mRNA is initially expressed at a lower level, but becomes male biased at later stages (after DMRT1 expression increase). AMH was expressed in a sexually dimorphic manner from E6.5. HPRT was used as the normalising control and error bars represent SEM, $n=3$. Reproduced from Lambeth et al., (2014), with permissions from Elsevier. 
pensable for embryonic mammalian testis development, with Dmrt1 null mice displaying a post-natal developmental defect (Raymond et al., 2000). Conditional knockouts of Dmrt1 in post-natal mice demonstrate that DMRT1 is required in both the Sertoli cells (which otherwise become reprogramed towards granulosa cells) and germ cells (to control the mitosis/meiosis decision) in order to maintain a functional testicular phenotype (Kim et al., 2007, Matson et al., 2010, Matson et al., 2011). Accordingly, mutations or deletions of $D M R T 1$ in humans are linked with male-to-female sex reversal in 46, $X Y$ individuals and an increased risk of germ cell tumours (Bennett et al., 1993, Kanetsky et al., 2011, Veitia et al., 1997).

In the chicken DMRT1 is Z-linked and expressed in the gonads of both genders (germ and somatic cells) and the Müllerian duct, but is more highly expressed in the male gonad (Omotehara et al., 2014). DMRT1 protein is clearly detectable by $\mathrm{E} 4.5(\mathrm{HH} 26)$ in the male (ZZ) embryonic chicken gonad (Fig. 6). Multiple lines of evidence in the chicken support the hypothesis that DMRT1 is the Z-dosage avian sex determinant. Among the first was observational data that $D M R T 1$ is upregulated in the gonads during female to male sex reversal of ZW embryos using the Aromatase inhibitor fadrozole (Smith et al., 2003). Functional validation has come largely from targeted RNAi mediated knockdown of DMRT1 using the RCASBP viral vector, with this in vivo knockdown approach feminising the left gonad of genetically male $(Z Z)$ chick embryos (Smith et al., 2009a). These gonads displayed female-like morphology, exhibited a loss of SOX9 expression (antagonism of the male pathway) and ectopic expression of Aromatase and FOXL2 (activation of female pathway). Over-expression of DMRT1 in genetically female (ZW) chick embryos has the converse effect on the gonads, inducing the male pathway (activation of SOX9 and $\mathrm{AMH}$ ), antagonising the female pathway (perturbation of Aromatase expression) and leads to male-like gonad morphology with medullary cells displaying seminiferous cord like organisation (Lambeth et al., 2014). Recent data from the zebra finch (Taeniopygia guttate) and emu (Dromaius novaehollandiae) have confirmed that the sexually dimorphic expression pattern of DMRT1 observed in the chicken, with increased DMRT1 levels in the male gonads, is conserved within a species from each of the three major bird clades (emu - Palaeognathae; chicken - Galloanserae; zebra finch - Neoaves; Prum et al., (2015)), suggesting that this mechanism is likely conserved across all birds (Hirst et al., 2017a).

All currently available evidence supports the notion that higher expression of Z-linked DMRT1 in the gonads of male (ZZ) chicks acts as the master gonadal sex determinant, triggering a molecular cascade that results in testis formation. Among the downstream targets activated by DMRT1 is SOX9, which is expressed in the developing testes of all vertebrate species examined thus far (Cutting et al., 2013), making it a conserved key molecular cornerstone of male gonadal development and Sertoli cell differentiation (Kent et al., 1996, Morais da Silva et al., 1996, Vidal et al., 2001). SOX9 protein expression is weak at E5.5 (H $\left.\mathrm{H}_{28}\right)$, but readily detected in the nuclei of pre-Sertoli cells in the medulla of the male chicken gonad by E6.5 (HH29), see Fig. 5 and 6A. Due to the time delay between DMRT1 expression (E4.5; HH26) and the peak in detectable SOX9 (E6.5; HH29), DMRT1 is thought to indirectly activate SOX9 expression (Chue and Smith, 2011). The transcription factor Hemogen (HEMGN) is a proposed chicken specific link between DMRT1 and SOX9 (Nakata et al., 2013). It displays male specific expression in the chicken gonad within the appropriate temporal window (Fig. 5 and 6), with HEMGN protein detected in groups of Sertoli cells by E5.5 (HH28). HEMGN overexpression using the RCASBP viral vector in genetically female (ZW) embryos resulted in male-like morphology of the gonad, activation of male markers (SOX9 and DMRT1), coupled with loss of the female associated genes CYP19A1 and FOXL2 (Nakata et al., 2013). It is currently unclear if HEMGN can act directly or indirectly to activate SOX9, while the upregulation of DMRT1 (upstream of HEMGN) suggests a positive feedback loop exists, reinforcing DMRT1 expression and the male gonadal differentiation pathway.

In mammals, a positive feedback loop exists between SOX9 and FGF9 (one of its downstream targets in the gonad), where each reinforces the other's expression to establish the Sertoli cell differentiation program while Fgf9 simultaneously supresses Wnt4 and the female pathway (Colvin et al., 2001, Kim et al., 2006). In the chicken gonad, however, FGF9 is expressed at a low level and appears to lack a sexually dimorphic expression pattern, suggesting that this mechanism is not conserved in the chicken (Fig. 5 and Ayers et al., (2015b)). Another SOX9 downstream target characterised in the mouse, Prostaglandin D Synthase (PGDS), also forms a positive feedback loop with SOX9 (Wilhelm et al., 2007). PGDS catalyses the isomerisation of prostaglandin $\mathrm{H} 2\left(\mathrm{PGH}_{2}\right)$ into prostaglandin $\mathrm{D} 2\left(\mathrm{PGD}_{2}\right)$, reviewed in Urade and Hayaishi (2000). PGD 2 acts to upregulate SOX9, thereby allowing the PGDS/PGD 2 pathway to act in an amplification loop with SOX9 (Moniot et al., 2009, Wilhelm et al., 2005). PGDSmRNA is detected within male (but not female) chicken gonads at E6.5 ( $\mathrm{HH} 29)$, when SOX9 mRNA can also be detected, suggesting that this pathway is conserved within the chicken (Moniot et al., 2008). Using organ culture of embryonic chicken gonads (and mesonephros) exogenous addition of $\mathrm{PGD}_{2}$ was shown activate SOX9 in genetically female ( $Z W)$ gonadal explants, but was insufficient to induce $A M H$ or full masculinisation of the female gonads in this in vitro culture system (Moniot et al., 2008).

$\mathrm{AMH}$ expression is upregulated in the male chicken urogenital system with protein readily detected in Sertoli cells along the length of the gonad by $\mathrm{E} 6.5$ (HH29), see Fig. 5 and 6 . The well characterised role of $\mathrm{AMH}$ during embryonic development in mammals is to drive regression of the Müllerian ducts in the male, and its expression is in part controlled by SOX9 during Sertoli cell development (Arango et al., 1999, De Santa Barbara et al., 1998, Josso and Picard, 1986). In the chicken, however, $A M H$ mRNA can be detected at E4.5 ( $\mathrm{HH} 26)$, ahead of SOX9, and it is also expressed in the gonads of both genders, unlike the mammal where it is only found in the male gonads during embryonic development (Oreal et al., 1998). This is not entirely surprising given that the right Müllerian duct regresses in the chicken, while the left is thought to be protected from $\mathrm{AMH}$ by the local actions of oestrogens (Hutson et al., 1982). AMH is required for testis development in several species of fish, some of which lack Müllerian ducts, suggesting that $\mathrm{AMH}$ may play roles in gonadal development in addition to Müllerian duct regression in other vertebrate species (Hattori et al., 2012, Kikuchi and Hamaguchi, 2013, Kluver et al., 2007, Morinaga et al., 2007, Nakamura et al., 2012). In the chicken, AMH receptor type-II (AMHR2), which recruits the type-I receptor for intracellular signal transduction, is expressed in the Müllerian ducts and gonads of both genders, but is upregulated in males during gonadal sex differentiation (Cutting et al., 2014). Knockdown of $A M H$ in chicken embryos using RNAi doesn't alter the ovarian or 
testicular development pathway, however, there was a reduction in the size of the mesonephros and gonads in both genders caused by a loss of proliferation in the cells of these tissues (Lambeth et al., 2015). Overexpression of AMH also had a detrimental effect on the gonads of both genders, forming underdeveloped gonad structures in embryo and the adult (Lambeth et al., 2016a). Female gonads in these animals developed testis-like cord morphology, but like their male counterparts (who had disrupted SOX9 expression), they both lacked Sertoli cells and the capacity for steroidogenesis (Lambeth et al., 2016a). Taken together, these cumulative results demonstrate that while $\mathrm{AMH}$ is important for gonadal development in the chicken, it does not have a deterministic role in chicken testis development, but can affect downstream events including steroid production.

\section{Conclusion}

The chicken is an excellent model to study the evolution of vertebrate sex determination, as birds combine elements of classic genetic sex determination and share several key genes with mammals, but also retain some features of lower vertebrates such as the central role for oestrogen. The differentiation of the gonads is under the control of several master molecular pathways that control the expression and activity of several important downstream factors, including the male enriched DMRT1, SOX9, PGDS and AMH as well as the female-specific FOXL2-Aromatase and RSPO1/ WNT4 pathways.

Until recently, studies into the role of the sex chromosomes, downstream signalling pathways and cell autonomous sex identity in chickens, had relied on either expression analysis or drugs to block the activity of specific genes. However, advances in the genetic manipulation in the chicken now allow functional analysis of candidate genes, through overexpression and knockdown strategies using the RCAS virus (Lambeth et al., 2015, Lambeth et al., 2016a) or electroporation (Ayers et al., 2015a, Hirst et al., 2017c). Furthermore, in ovo CRISPR/Cas9 mediated gene targeting has been shown to be a potential tool to achieve loss of function experiments in the chicken (Veron et al., 2015). The integration of data from these gene knockdown and over expression studies, together with analysis of the transcriptome and epigenome will further our understanding of the key regulatory genes involved in sex determination and gonadal differentiation.

\section{References}

ABINAWANTO, SHIMADA, K., YOSHIDA, K. and SAITO, N. (1996). Effects of aromatase inhibitor on sex differentiation and levels of P450 (17 alpha) and P450 arom messenger ribonucleic acid of gonads in chicken embryos. Gen Comp Endocrinol 102: 241-246.

AGATE, R.J., GRISHAM, W., WADE, J., MANN, S., WINGFIELD, J., SCHANEN, C., PALOTIE, A. and ARNOLD, A.P. (2003). Neural, not gonadal, origin of brain sex differences in a gynandromorphic finch. Proc Natl Acad Sci USA 100: 4873-4878.

ARANGO, N.A., LOVELL-BADGE, R. and BEHRINGER, R.R. (1999). Targeted mutagenesis of the endogenous mouse Mis gene promoter: in vivo definition of genetic pathways of vertebrate sexual development. Cell 99: 409-419.

ARNOLD, A.P. (1996). Genetically triggered sexual differentiation of brain and behavior. Horm Behav 30: 495-505.

ARNOLD, A.P. (2012). The end of gonad-centric sex determination in mammals. Trends Genet 28: 55-61.

ARNOLD, A.P., CHEN, X., LINK, J.C., ITOH, Y. and REUE, K. (2013). Cell-autonomous sex determination outside of the gonad. Dev Dyn 242: 371-379.
ARNOLD, A.P. and ITOH, Y. (2011). Factors causing sex differences in birds. Avian Biol Res 4.

ARNOLD, A.P., ITOH, Y. and MELAMED, E. (2008). A bird's-eye view of sex chromosome dosage compensation. Annu Rev Genomics Hum Genet 9: 109-127.

AYERS, K.L., CUTTING, A.D., ROESZLER, K.N., SINCLAIR, A.H. and SMITH, C.A. (2015a). DMRT1 is required for Mullerian duct formation in the chicken embryo. Dev. Biol. 400: 224-236.

AYERS, K.L., DAVIDSON, N.M., DEMIYAH, D., ROESZLER, K.N., GRUTZNER, F., SINCLAIR, A.H., OSHLACK, A. and SMITH, C.A. (2013a). RNA sequencing reveals sexually dimorphic gene expression before gonadal differentiation in chicken and allows comprehensive annotation of the W-chromosome. Genome Biol 14: R26.

AYERS, K.L., LAMBETH, L.S., DAVIDSON, N.M., SINCLAIR, A.H., OSHLACK, A. and SMITH, C.A. (2015b). Identification of candidate gonadal sex differentiation genes in the chicken embryo using RNA-seq. BMC Genomics 16: 704.

AYERS, K.L., SINCLAIR, A.H. and SMITH, C.A. (2013b). The molecular genetics of ovarian differentiation in the avian model. Sex Dev 7: 80-94.

BELLOTT, D.W., SKALETSKY, H., CHO, T.J., BROWN, L., LOCKE, D., CHEN, N., GALKINA, S., PYNTIKOVA, T., KOUTSEVA, N., GRAVES, T. et al., (2017). Avian $\mathrm{W}$ and mammalian $\mathrm{Y}$ chromosomes convergently retained dosage-sensitive regulators. Nat Genet 49: 387-394.

BELLOTT, D.W., SKALETSKY, H., PYNTIKOVA, T., MARDIS, E.R., GRAVES, T., KREMITZKI, C., BROWN, L.G., ROZEN, S., WARREN, W.C., WILSON, R.K. et al., (2010). Convergent evolution of chicken $Z$ and human $X$ chromosomes by expansion and gene acquisition. Nature 466: 612-616.

BENNETT, C.P., DOCHERTY, Z., ROBB, S.A., RAMANI, P., HAWKINS, J.R. and GRANT, D. (1993). Deletion 9p and sex reversal. J Med Genet 30: 518-520.

BENTSI-BARNES, I.K., KUO, F.T., BARLOW, G.M. and PISARSKA, M.D. (2010). Human forkhead $L 2$ represses key genes in granulosa cell differentiation including aromatase, P450scc, and cyclin D2. Fertil Steril 94: 353-356.

BIASON-LAUBER, A., DE FILIPPO, G., KONRAD, D., SCARANO, G., NAZZARO, A. and SCHOENLE, E.J. (2007). WNT4 deficiency--a clinical phenotype distinct from the classic Mayer-Rokitansky-Kuster-Hauser syndrome: a case report. Hum Reprod 22: 224-229.

BIASON-LAUBER, A. and KONRAD, D. (2008). WNT4 and sex development. Sex Dev 2: 210-218.

BIASON-LAUBER, A., KONRAD, D., NAVRATIL, F. and SCHOENLE, E.J. (2004). A WNT4 mutation associated with Mullerian-duct regression and virilization in a 46,XX woman. N Engl J Med 351: 792-798.

BINNERTS, M.E., KIM, K.A., BRIGHT, J.M., PATEL, S.M., TRAN, K., ZHOU, M., LEUNG, J.M., LIU, Y., LOMAS, W.E., 3RD, DIXON, M. et al. (2007). R-Spondin1 regulates Wnt signaling by inhibiting internalization of LRP6. Proc Natl Acad Sci USA 104: 14700-5.

BISONI, L., BATLLE-MORERA, L., BIRD, A.P., SUZUKI, M. and MCQUEEN, H.A. (2005). Female-specific hyperacetylation of histone $\mathrm{H} 4$ in the chicken $\mathrm{Z}$ chromosome. Chromosome Res 13: 205-214.

BRENNER, C. (2002). Hint, Fhit, and GalT: function, structure, evolution, and mechanism of three branches of the histidine triad superfamily of nucleotide hydrolases and transferases. Biochemistry 41: 9003-9014.

BRENNER, C., BIEGANOWSKI, P., PACE, H.C. and HUEBNER, K. (1999). The histidine triad superfamily of nucleotide-binding proteins. J Cell Physiol 181: 179-187.

BRIGGS, S.F. and REIJO PERA, R.A. (2014). X chromosome inactivation: recent advances and a look forward. Curr Opin Genet Dev 28: 78-82.

BRUGGEMAN, V., VAN AS, P. and DECUYPERE, E. (2002). Developmental endocrinology of the reproductive axis in the chicken embryo. Comp Biochem Physiol A Mol Integr Physiol 131: 839-846.

BURKE, W.H. and HENRY, M.H. (1999). Gonadal development and growth of chickens and turkeys hatched from eggs injected with an aromatase inhibitor. Poult Sci 78: 1019-1033.

CAETANO, L.C., GENNARO, F.G., COELHO, K., ARAUJO, F.M., VILA, R.A., ARAUJO, A., DE MELO BERNARDO, A., MARCONDES, C.R., CHUVADE SOUSALOPES, S.M. and RAMOS, E.S. (2014). Differential expression of the MHM region and of sex-determining-related genes during gonadal development in chicken embryos. Genet Mol Res 13: 838-849.

CARLON, N. and STAHL, A. (1985). Origin of the somatic components in chick embryonic gonads. Arch Anat Microsc Morphol Exp 74: 52-59. 
CARRE, G.A., COUTY, I., HENNEQUET-ANTIER, C. and GOVOROUN, M.S. (2011). Gene expression profiling reveals new potential players of gonad differentiation in the chicken embryo. PloS One 6: e23959.

CHASSOT, A.A., RANC, F., GREGOIRE, E.P., ROEPERS-GAJADIEN, H.L., TAKETO, M.M., CAMERINO, G., DE ROOIJ, D.G., SCHEDL, A. and CHABOISSIER, M.C. (2008). Activation of beta-catenin signaling by Rspo1 controls differentiation of the mammalian ovary. Hum Mol Genet 17: 1264-1277.

CHEN, G., YANG, L., BEGUM, S. and XU, L. (2010). GPR56 is essential for testis development and male fertility in mice. Dev Dyn 239: 3358-3367.

CHUE, J. and SMITH, C.A. (2011). Sex determination and sexual differentiation in the avian model. FEBS J 278: 1027-1034.

CLINTON, M., ZHAO, D., NANDI, S. and MCBRIDE, D. (2012). Evidence for avian cell autonomous sex identity (CASI) and implications for the sex-determination process? Chromosome Res 20: 177-190.

COLVIN, J.S., GREEN, R.P., SCHMAHL, J., CAPEL, B. and ORNITZ, D.M. (2001). Male-to-female sex reversal in mice lacking fibroblast growth factor 9. Cell 104: 875-889.

CUTTING, A., CHUE, J. and SMITH, C.A. (2013). Just how conserved is vertebrate sex determination? Dev Dyn 242: 380-387.

CUTTING, A.D., AYERS, K., DAVIDSON, N., OSHLACK, A., DORAN, T., SINCLAIR, A.H., TIZARD, M. and SMITH, C.A. (2014). Identification, expression, and regulation of anti-Mullerian hormone type-Il receptor in the embryonic chicken gonad. Biol. Reprod. 90: 106.

DE MELO BERNARDO, A., HEEREN, A.M., VAN IPEREN, L., FERNANDES, M.G., HE, N., ANJIE, S., NOCE, T., RAMOS, E.S. and DE SOUSA LOPES, S.M. (2015). Meiotic wave adds extra asymmetry to the development of female chicken gonads. Mol Reprod Dev 82: 774-786

DE SANTA BARBARA, P., BONNEAUD, N., BOIZET, B., DESCLOZEAUX, M., MONIOT, B., SUDBECK, P., SCHERER, G., POULAT, F. and BERTA, P. (1998). Direct interaction of SRY-related protein SOX9 and steroidogenic factor 1 regulates transcription of the human anti-Mullerian hormone gene. Mol Cell Biol 18: 6653-6665.

DEAR, N., MATENA, K., VINGRON, M. and BOEHM, T. (1997). A new subfamily of vertebrate calpains lacking a calmodulin-like domain: implications for calpain regulation and evolution. Genomics 45: 175-184.

DORAN, T.J., COOPER, C.A., JENKINS, K.A. and TIZARD, M.L. (2016). Advances in genetic engineering of the avian genome: "Realising the promise". Transgenic Res 25: 307-319.

DORAN, T.J., MORRIS, K.R., WISE, T.G., O'NEIL, T.E., COOPER, C.A., JENKINS, K.A. and TIZARD, M.L.V. (2017). Sex selection in layer chickens. Animal Prod. Sci. 58: 476-480. (https://doi.org/10.1071/AN16785)

ELBRECHT, A. and SMITH, R.G. (1992a). Aromatase enzyme activity and sex determination in chickens. Science 255: 467-470.

ELBRECHT, A. and SMITH, R.G. (1992b). Aromatase Enzyme-Activity and Sex Determination in Chickens. Science 255: 467-470.

ELLEGREN, H. (2011). Emergence of male-biased genes on the chicken Z-chromosome: sex-chromosome contrasts between male and female heterogametic systems. Genome Res 21: 2082-2086.

ELLEGREN, H., HULTIN-ROSENBERG, L., BRUNSTROM, B., DENCKER, L., KULTIMA, K. and SCHOLZ, B. (2007). Faced with inequality: chicken do not have a general dosage compensation of sex-linked genes. BMC Biol 5: 40.

FLEMING, N.I., KNOWER, K.C., LAZARUS, K.A., FULLER, P.J., SIMPSON, E.R and CLYNE, C.D. (2010). Aromatase is a direct target of FOXL2: C134W in granulosa cell tumors via a single highly conserved binding site in the ovarian specific promoter. PloS one 5: e14389.

FRANZ, T., WINCKLER, L., BOEHM, T. and DEAR, T.N. (2004). Capn5 is expressed in a subset of T cells and is dispensable for development. Mol Cell Biol24: 1649-1654.

GARCIA-ORTIZ, J.E., PELOSI, E., OMARI, S., NEDOREZOV, T., PIAO, Y., KARMAZIN, J., UDA, M., CAO, A., COLE, S.W., FORABOSCO, A. et al., (2009). Foxl2 functions in sex determination and histogenesis throughout mouse ovary development. BMC Dev Biol 9: 36.

GE, C., YE, J., ZHANG, H., ZHANG, Y., SUN, W., SANG, Y., CAPEL, B. and QIAN, G. (2017). Dmrt1 induces the male pathway in a turtle species with temperaturedependent sex determination. Development 144: 2222-2233.

GINSBURG, M. and EYAL-GILADI, H. (1987). Primordial germ cells of the young chick blastoderm originate from the central zone of the area pellucida irrespective of the embryo-forming process. Development 101: 209-219.
GONZALEZ, A., SAEZ, M.E., ARAGON, M.J., GALAN, J.J., VETTORI, P., MOLINA, L., RUBIO, C., REAL, L.M., RUIZ, A. and RAMIREZ-LORCA, R. (2006). Specific haplotypes of the CALPAIN-5 gene are associated with polycystic ovary syndrome. Hum Reprod 21: 943-951.

GOVOROUN, M.S., PANNETIER, M., PAILHOUX, E., COCQUET, J., BRILLARD, J.P., COUTY, I., BATELLIER, F. and COTINOT, C. (2004). Isolation of chicken homolog of the FOXL2 gene and comparison of its expression patterns with those of aromatase during ovarian development. Dev Dyn 231: 859-870.

GRAVES, J.A. (2016). Evolution of vertebrate sex chromosomes and dosage compensation. Nat Rev Genet 17: 33-46.

GUIOLI, S. and LOVELL-BADGE, R. (2007). PITX2 controls asymmetric gonadal development in both sexes of the chick and can rescue the degeneration of the right ovary. Development 134: 4199-4208.

HANDLEY, L.J., CEPLITIS, H. and ELLEGREN, H. (2004). Evolutionary strata on the chicken $Z$ chromosome: implications for sex chromosome evolution. Genetics 167: 367-376.

HATTORI, R.S., MURAI, Y., OURA, M., MASUDA, S., MAJHI, S.K., SAKAMOTO, T., FERNANDINO, J.I., SOMOZA, G.M., YOKOTA, M. and STRUSSMANN, C.A. (2012). A Y-linked anti-Mullerian hormone duplication takes over a critical role in sex determination. Proc Natl Acad Sci USA 109: 2955-2959.

HIRST, C.E., MAJOR, A.T., AYERS, K.L., BROWN, R.J., MARIETTE, M., SACKTON, T.B. and SMITH, C.A. (2017). Sex Reversal and Comparative Data Undermine the W Chromosome and Support Z-linked DMRT1 as the Regulator of Gonadal Sex Differentiation in Birds. Endocrinology 158: 2970-2987.

HIRST, C.E., MAJOR, A.T., AYERS, K.L., BROWN, R.J., MARIETTE, M., SACKTON, T.B. and SMITH, C.A. (2017b). Sex Reversal and Comparative Data Undermine the W Chromosome and Support Z-linked DMRT1 as the Regulator of Gonadal Sex Differentiation in Birds. Endocrinol. 158: 2970-2987.

HIRST, C.E., SERRALBO, O., AYERS, K.L., ROESZLER, K.N. and SMITH, C.A. (2017c). Genetic Manipulation of the Avian Urogenital System Using in ovo Electroporation. In Avian and Reptilian Developmental Biology: Methods and Protocols, (ed. SHENG, G.). Springer New York, New York, NY, pp.177-190.

HORI, T., ASAKAWA, S., ITOH, Y., SHIMIZU, N. and MIZUNO, S. (2000). Wpkci, encoding an altered form of $\mathrm{PKCl}$, is conserved widely on the avian $\mathrm{W}$ chromosome and expressed in early female embryos: implication of its role in female sex determination. Mol Biol Cell 11: 3645-3660.

HU, Y.C., OKUMURA, L.M. and PAGE, D.C. (2013). Gata4 is required for formation of the genital ridge in mice. PLoS Genet 9: e1003629.

HUDSON, Q.J., SMITH, C.A. and SINCLAIR, A.H. (2005). Aromatase inhibition reduces expression of FOXL2 in the embryonic chicken ovary. Dev Dyn 233: 1052-1055.

HUTSON, J.M., IKAWA, H. and DONAHOE, P.K. (1982). Estrogen inhibition of Mullerian inhibiting substance in the chick embryo. J Pediatr Surg 17: 953-959.

IKEDA, Y., SHEN, W.H., INGRAHAM, H.A. and PARKER, K.L. (1994). Developmental expression of mouse steroidogenic factor-1, an essential regulator of the steroid hydroxylases. Mol Endocrinol 8: 654-662.

IMATAKA, H., SUZUKI, K., INANO, H., KOHMOTO, K. and TAMAOKI, B. (1989). Biosynthetic pathways of testosterone and estradiol-17 beta in slices of the embryonic ovary and testis of the chicken (Gallus domesticus). Gen Comp Endocrinol 73: 69-79.

ISHIMARU, Y., KOMATSU, T., KASAHARA, M., KATOH-FUKUI, Y., OGAWA, H., TOYAMA, Y., MAEKAWA, M., TOSHIMORI, K., CHANDRARATNA, R.A., MOROHASHI, K. et al., (2008). Mechanism of asymmetric ovarian development in chick embryos. Development 135: 677-685.

ITOH, Y., KAMPF, K. and ARNOLD, A.P. (2011). Possible differences in the two Z chromosomes in male chickens and evolution of MHM sequences in Galliformes. Chromosoma 120: 587-598

ITOH, Y., MELAMED, E., YANG, X., KAMPF, K., WANG, S., YEHYA, N., VAN NAS, A., REPLOGLE, K., BAND, M. and CLAYTON, D. (2007). Dosage compensation is less effective in birds than in mammals. J. Biology 6: 2.

ITOH, Y., REPLOGLE, K., KIM, Y.H., WADE, J., CLAYTON, D.F. and ARNOLD, A.P. (2010). Sex bias and dosage compensation in the zebra finch versus chicken genomes: general and specialized patterns among birds. Genome Res 20:512-8.

JOSSO, N. and PICARD, J.Y. (1986). Anti-Mullerian hormone. Physiol Rev 66 1038-1090.

JOST, A., VIGIER, B., PREPIN, J. and PERCHELLET, J.P. (1973). Studies on sex differentiation in mammals. Recent Prog Horm Res 29: 1-41. 
KAISER, V.B. and ELLEGREN, H. (2006). Nonrandom distribution of genes with sexbiased expression in the chicken genome. Evolution 60: 1945-1951.

KANETSKY, P.A., MITRA, N., VARDHANABHUTI, S., VAUGHN, D.J., LI, M., CIOSEK, S.L., LETRERO, R., D'ANDREA, K., VADDI, M., DOODY, D.R. et al., (2011). A second independent locus within DMRT1 is associated with testicular germ cell tumor susceptibility. Hum Mol Genet 20: 3109-3117.

KENT, J., WHEATLEY, S.C., ANDREWS, J.E., SINCLAIR, A.H. and KOOPMAN, P. (1996). A male-specific role for SOX9 in vertebrate sex determination. Development 122: 2813-2822.

KIKUCHI, K. and HAMAGUCHI, S. (2013). Novel sex-determining genes in fish and sex chromosome evolution. Dev Dyn 242: 339-353.

KIM, S., BARDWELL, V.J. and ZARKOWER, D. (2007). Cell type-autonomous and non-autonomous requirements for Dmrt1 in postnatal testis differentiation. Dev. Biol. 307: 314-327.

KIM, Y., KOBAYASHI, A., SEKIDO, R., DINAPOLI, L., BRENNAN, J., CHABOISSIER, M.C., POULAT, F., BEHRINGER, R.R., LOVELL-BADGE, R. and CAPEL, B. (2006). Fgf9 and Wnt4 act as antagonistic signals to regulate mammalian sex determination. PLOS Biol 4: e187.

KLUVER, N., PFENNIG, F., PALA, I., STORCH, K., SCHLIEDER, M., FROSCHAUER, A., GUTZEIT, H.O. and SCHARTL, M. (2007). Differential expression of antiMullerian hormone (amh) and anti-Mullerian hormone receptor type II (amhrll) in the teleost medaka. Dev Dyn 236: 271-281.

KURODA, Y., ARAI, N., ARITA, M., TERANISHI, M., HORI, T., HARATA, M. and MIZUNO, S. (2001). Absence of Z-chromosome inactivation for five genes in male chickens. Chromosome Res 9: 457-468.

LAMBETH, L.S., AYERS, K., CUTTING, A.D., DORAN, T.J., SINCLAIR, A.H. and SMITH, C.A. (2015). Anti-Mullerian Hormone Is Required for Chicken Embryonic Urogenital System Growth but Not Sexual Differentiation. Biol. Reprod. 93: 138.

LAMBETH, L.S., CUMMINS, D.M., DORAN, T.J., SINCLAIR, A.H. and SMITH, C.A. (2013). Overexpression of aromatase alone is sufficient for ovarian development in genetically male chicken embryos. PloS One 8: e68362.

LAMBETH, L.S., MORRIS, K., AYERS, K.L., WISE, T.G., O'NEIL, T., WILSON, S., CAO, Y., SINCLAIR, A.H., CUTTING, A.D., DORAN, T.J. et al., (2016a). Overexpression of Anti-Mullerian Hormone Disrupts Gonadal Sex Differentiation, Blocks Sex Hormone Synthesis, and Supports Cell Autonomous Sex Development in the Chicken. Endocrinology 157: 1258-1275.

LAMBETH, L.S., MORRIS, K.R., WISE, T.G., CUMMINS, D.M., O'NEIL, T.E., CAO, Y., SINCLAIR, A.H., DORAN, T.J. and SMITH, C.A. (2016b). Transgenic Chickens Overexpressing Aromatase Have High Estrogen Levels but Maintain a Predominantly Male Phenotype. Endocrinology 157: 83-90.

LAMBETH, L.S., RAYMOND, C.S., ROESZLER, K.N., KUROIWA, A., NAKATA, T., ZARKOWER, D. and SMITH, C.A. (2014). Over-expression of DMRT1 induces the male pathway in embryonic chicken gonads. Dev. Biol. 389: 160-72.

LAMBETH, L.S. and SMITH, C.A. (2012). Disorders of sexual development in poultry. Sex Dev 6: 96-103.

LIN, Y.P., CHEN, L.R., CHEN, C.F., LIOU, J.F., CHEN, Y.L., YANG, J.R. and SHIUE, Y.L. (2010). Identification of early transcripts related to male development in chicken embryos. Theriogenology 74: 1161-1178 e1-8.

LIU, C.F., BINGHAM, N., PARKER, K. and YAO, H.H. (2009). Sex-specific roles of beta-catenin in mouse gonadal development. Hum Mol Genet 18: 405-417.

LIU, C.F., LIU, C. and YAO, H.H. (2010). Building pathways for ovary organogenesis in the mouse embryo. Curr Top Dev Biol 90: 263-290.

LOFFLER, K.A., ZARKOWER, D. and KOOPMAN, P. (2003). Etiology of ovarian failure in blepharophimosis ptosis epicanthus inversus syndrome: FOXL2 is a conserved, early-acting gene in vertebrate ovarian development. Endocrinology 144: 3237-3243.

LUO, X., IKEDA, Y. and PARKER, K.L. (1994). A cell-specific nuclear receptor is essential for adrenal and gonadal development and sexual differentiation. Cell 77: 481-490.

MAEKAWA, F., SAKURAI, M., YAMASHITA, Y., TANAKA, K., HARAGUCHI, S., YAMAMOTO, K., TSUTSUI, K., YOSHIOKA, H., MURAKAMI, S., TADANO, R. et al., (2013). A genetically female brain is required for a regular reproductive cycle in chicken brain chimeras. Nat Commun 4: 1372.

MAJOR, A.T. and SMITH, C.A. (2016). Sex Reversal in Birds. Sex Dev 10: 288-300.

MANDEL, H., SHEMER, R., BOROCHOWITZ, Z.U., OKOPNIK, M., KNOPF, C., INDELMAN, M., DRUGAN, A., TIOSANO, D., GERSHONI-BARUCH, R., CHODER,
M. et al., (2008). SERKAL syndrome: an autosomal-recessive disorder caused by a loss-of-function mutation in WNT4. Am J Hum Genet 82: 39-47.

MANK, J.E., AXELSSON, E. and ELLEGREN, H. (2007). Fast-X on the Z: rapid evolution of sex-linked genes in birds. Genome Res 17: 618-624.

MANK, J.E. and ELLEGREN, H. (2007). Parallel divergence and degradation of the avian W sex chromosome. Trends Ecol Evol 22: 389-391.

MANK, J.E. and ELLEGREN, H. (2009). All dosage compensation is local: gene-bygene regulation of sex-biased expression on the chicken $Z$ chromosome. Heredity (Edinb) 102: 312-320.

MATSON, C.K., MURPHY, M.W., GRISWOLD, M.D., YOSHIDA, S., BARDWELL, V.J. and ZARKOWER, D. (2010). The mammalian doublesex homolog DMRT1 is a transcriptional gatekeeper that controls the mitosis versus meiosis decision in male germ cells. Dev Cell 19: 612-624.

MATSON, C.K., MURPHY, M.W., SARVER, A.L., GRISWOLD, M.D., BARDWELL, V.J. and ZARKOWER, D. (2011). DMRT1 prevents female reprogramming in the postnatal mammalian testis. Nature 476: 101-104.

MATSON, C.K. and ZARKOWER, D. (2012). Sex and the singular DM domain: insights into sexual regulation, evolution and plasticity. Nat Rev Genet 13: 163-174.

MATSUDA, M., NAGAHAMA, Y., SHINOMIYA, A., SATO, T., MATSUDA, C., KOBAYASHI, T., MORREY, C.E., SHIBATA, N., ASAKAWA, S., SHIMIZU, N. et al., (2002). DMY is a Y-specific DM-domain gene required for male development in the medaka fish. Nature 417: 559-563.

MATSUDA, M., SHINOMIYA, A., KINOSHITA, M., SUZUKI, A., KOBAYASHI, T., PAULPRASANTH, B., LAU, E.L., HAMAGUCHI, S., SAKAIZUMI, M. and NAGAHAMA, Y (2007). DMY gene induces male development in genetically female (XX) medaka fish. Proc Natl Acad Sci USA 104: 3865-3870.

MCQUEEN, H.A. and CLINTON, M. (2009). Avian sex chromosomes: dosage compensation matters. Chromosome Res 17: 687-697.

MELAMED, E. and ARNOLD, A.P. (2007). Regional differences in dosage compensation on the chicken Z chromosome. Genome Biol 8: R202.

MOGHADAM, H.K., POINTER, M.A., WRIGHT, A.E., BERLIN, S. and MANK, J.E. (2012). W chromosome expression responds to female-specific selection. Proc Natl Acad Sci USA 109: 8207-8211.

MONIOT, B., BOIZET-BONHOURE, B. and POULAT, F. (2008). Male specific expression of lipocalin-type prostaglandin D synthase (CPTGDS) during chicken gonada differentiation: relationship with cSOX9. Sex Dev 2: 96-103.

MONIOT, B., DECLOSMENIL, F., BARRIONUEVO, F., SCHERER, G., ARITAKE, K., MALKI, S., MARZI, L., COHEN-SOLAL, A., GEORG, I., KLATTIG, J. et al., (2009). The PGD2 pathway, independently of FGF9, amplifies SOX9 activity in Sertoli cells during male sexual differentiation. Development 136: 1813-1821.

MORAIS DA SILVA, S., HACKER, A., HARLEY, V., GOODFELLOW, P., SWAIN, A. and LOVELL-BADGE, R. (1996). Sox9 expression during gonadal development implies a conserved role for the gene in testis differentiation in mammals and birds. Nat Genet 14: 62-68.

MORINAGA, C., SAITO, D., NAKAMURA, S., SASAKI, T., ASAKAWA, S., SHIMIZU, N., MITANI, H., FURUTANI-SEIKI, M., TANAKA, M. and KONDOH, H. (2007) The hotei mutation of medaka in the anti-Mullerian hormone receptor causes the dysregulation of germ cell and sexual development. Proc Natl Acad Sci USA 104: 9691-9696.

MORIYAMA, S., OGIHARA, J., KATO, J., HORI, T. and MIZUNO, S. (2006). PKCI-W forms a heterodimer with $\mathrm{PKCl}-\mathrm{Z}$ and inhibits the biological activities of $\mathrm{PKCl}-\mathrm{Z}$ in vitro, supporting the predicted role of $\mathrm{PKCl}-\mathrm{W}$ in sex determination in birds. $J$ Biochem 139: 91-97.

MORKOVSKY, L., STORCHOVA, R., PLACHY, J., IVANEK, R., DIVINA, P. and HEJNAR, J. (2010). The chicken Zchromosome is enriched for genes with preferential expression in ovarian somatic cells. J Mol Evol 70: 129-136.

MUGITA, N., KIMURA, Y., OGAWA, M., SAYA, H. and NAKAO, M. (1997). Identification of a novel, tissue-specific calpain htra-3; a human homologue of the Caenorhabditis elegans sex determination gene. Biochem Biophys Res Commun 239: 845-850.

NAKABAYASHI, O., KIKUCHI, H., KIKUCHI, T. and MIZUNO, S. (1998). Differential expression of genes for aromatase and estrogen receptor during the gonadal development in chicken embryos. J Mol Endocrinol 20: 193-202.

NAKAMURA, S., WATAKABE, I., NISHIMURA, T., PICARD, J.Y., TOYODA, A. TANIGUCHI, Y., DI CLEMENTE, N. and TANAKA, M. (2012). Hyperproliferation of mitotically active germ cells due to defective anti-Mullerian hormone signaling mediates sex reversal in medaka. Development 139: 2283-2287. 
NAKATA, T., ISHIGURO, M., ADUMA, N., IZUMI, H. and KUROIWA, A. (2013). Chicken hemogen homolog is involved in the chicken-specific sex-determining mechanism. Proc Natl Acad Sci USA 110: 3417-3422.

NANDA, I., KONDO, M., HORNUNG, U., ASAKAWA, S., WINKLER, C., SHIMIZU, A., SHAN, Z., HAAF, T., SHIMIZU, N., SHIMA, A. et al., (2002). A duplicated copy of DMRT1 in the sex-determining region of the $\mathrm{Y}$ chromosome of the medaka, Oryzias latipes. Proc Natl Acad Sci USA 99: 11778-11783.

NAURIN, S., HASSELQUIST, D., BENSCH, S. and HANSSON, B. (2012). Sex-biased gene expression on the avian $Z$ chromosome: highly expressed genes show higher male-biased expression. PloS one 7: e46854.

NISHIKIMI, H., KANSAKU, N., SAITO, N., USAMI, M., OHNO, Y. and SHIMADA, K. (2000). Sex differentiation and mRNA expression of P450c17, P450arom and $\mathrm{AMH}$ in gonads of the chicken. Mol Reprod Dev 55: 20-30.

O'NEILL, M., BINDER, M., SMITH, C., ANDREWS, J., REED, K., SMITH, M., MILLAR, C., LAMBERT, D. and SINCLAIR, A. (2000). ASW: a gene with conserved avian W-linkage and female specific expression in chick embryonic gonad. Dev Genes Evol 210: 243-249.

OKADA, E., YOSHIMOTO, S., IKEDA, N., KANDA, H., TAMURA, K., SHIBA, T., TAKAMATSU, N. and ITO, M. (2009). Xenopus W-linked DM-W induces FoxI2 and Cyp19 expression during ovary formation. Sex Dev 3: 38-42.

OMOTEHARA, T., SMITH, C.A., MANTANI, Y., KOBAYASHI, Y., TATSUMI, A., NAGAHARA, D., HASHIMOTO, R., HIRANO, T., UMEMURA, Y., YOKOYAMA, T. et al., (2014). Spatiotemporal expression patterns of doublesex and mab-3 related transcription factor 1 in the chicken developing gonads and Mullerian ducts. Poult Sci 93: 953-958.

OREAL, E., MAZAUD, S., PICARD, J.Y., MAGRE, S. and CARRE-EUSEBE, D. (2002). Different patterns of anti-Mullerian hormone expression, as related to DMRT1, SF-1, WT1, GATA-4, Wnt-4, and Lhx9 expression, in the chick differentiating gonads. Dev Dyn 225: 221-232.

OREAL, E., PIEAU, C., MATTEI, M.G., JOSSO, N., PICARD, J.Y., CARRE-EUSEBE, D. and MAGRE, S. (1998). Early expression of $A M H$ in chicken embryonic gonads precedes testicular SOX9 expression. Dev Dyn 212: 522-532.

OTTOLENGHI, C., OMARI, S., GARCIA-ORTIZ, J.E., UDA, M., CRISPONI, L., FORABOSCO, A., PILIA, G. and SCHLESSINGER, D. (2005). FoxI2 is required for commitment to ovary differentiation. Hum Mol Genet 14: 2053-2062.

OWENS, I.P. and SHORT, R.V. (1995). Hormonal basis of sexual dimorphism in birds: implications for new theories of sexual selection. Trends Ecol Evol 10: 44-47.

PACE, H.C. and BRENNER, C. (2003). Feminizing chicks: a model for avian sex determination based on titration of Hint enzyme activity and the predicted structure of an Asw-Hint heterodimer. Genome Biol 4: R18.

PANNETIER, M., FABRE, S., BATISTA, F., KOCER, A., RENAULT, L., JOLIVET, G. MANDON-PEPIN, B., COTINOT, C., VEITIA, R. and PAILHOUX, E. (2006). FOXL2 activates $\mathrm{P} 450$ aromatase gene transcription: towards a better characterization of the early steps of mammalian ovarian development. JMol Endocrino/36:399-413.

PARKS, K.P., SEIDLE, H., WRIGHT, N., SPERRY, J.B., BIEGANOWSKI, P., HOWITZ, K., WRIGHT, D.L. and BRENNER, C. (2004). Altered specificity of Hint-W123Q supports a role for Hint inhibition by ASW in avian sex determination. Physiol Genomics 20: 12-14.

PARMA, P., RADI, O., VIDAL, V., CHABOISSIER, M.C., DELLAMBRA, E., VALENTINI, S., GUERRA, L., SCHEDL, A. and CAMERINO, G. (2006). R-spondin1 is essential in sex determination, skin differentiation and malignancy. Nat Genet38: 1304-1309.

PIPREK, R.P., KLOC, M. and KUBIAK, J.Z. (2016). Early Development of the Gonads: Origin and Differentiation of the Somatic Cells of the Genital Ridges. In Molecular Mechanisms of Cell Differentiation in Gonad Development, (ed. PIPREK, R. P.). Springer International Publishing, Cham, pp.1-22

PISARSKA, M.D., BARLOW, G. and KUO, F.T. (2011). Minireview: roles of the forkhead transcription factor FOXL2 in granulosa cell biology and pathology. Endocrinology 152: 1199-1208.

PRUM, R.O., BERV, J.S., DORNBURG, A., FIELD, D.J., TOWNSEND, J.P., LEMMON, E.M. and LEMMON, A.R. (2015). A comprehensive phylogeny of birds (Aves) using targeted next-generation DNA sequencing. Nature 526: 569-573.

RAYMOND, C.S., KETTLEWELL, J.R., HIRSCH, B., BARDWELL, V.J. and ZARKOWER, D. (1999). Expression of Dmrt1 in the genital ridge of mouse and chicken embryos suggests a role in vertebrate sexual development. Dev. Biol. 215:208-220.

RAYMOND, C.S., MURPHY, M.W., O'SULLIVAN, M.G., BARDWELL, V.J. and ZARKOWER, D. (2000). Dmrt1, a gene related to worm and fly sexual regulators, is required for mammalian testis differentiation. Genes Dev. 14: 2587-2595.

RAYMOND, C.S., SHAMU, C.E., SHEN, M.M., SEIFERT, K.J., HIRSCH, B., HODGKIN, J. and ZARKOWER, D. (1998). Evidence for evolutionary conservation of sex-determining genes. Nature 391: 691-695.

RODRIGUEZ-LEON, J., RODRIGUEZ ESTEBAN, C., MARTI, M., SANTIAGOJOSEFAT, B., DUBOVA, I., RUBIRALTA, X. and IZPISUABELMONTE, J.C. (2008). Pitx2 regulates gonad morphogenesis. Proc NatIAcad SciUSA 105: 11242-11247.

ROESZLER, K.N., ITMAN, C., SINCLAIR, A.H. and SMITH, C.A. (2012). The long non-coding RNA, MHM, plays a role in chicken embryonic development, including gonadogenesis. Dev. Biol. 366: 317-326.

SCHEIB, D. (1983). Effects and role of estrogens in avian gonadal differentiation. Differentiation 23 Suppl: S87-92.

SCHMID, M.SMITH, J.BURT, D.W.AKEN, B.L.ANTIN, P.B.ARCHIBALD, A.L.ASHWELL, C.BLACKSHEAR, P.J.BOSCHIERO, C.BROWN, C.T. et al., (2015). Third Report on Chicken Genes and Chromosomes 2015. Cytogenet Genome Res 145: 78-179.

SCHOLZ, B., KULTIMA, K., MATTSSON, A., AXELSSON, J., BRUNSTROM, B., HALLDIN, K., STIGSON, M. and DENCKER, L. (2006). Sex-dependent gene expression in early brain development of chicken embryos. BMC Neurosci 7: 12.

SHAN, Z., NANDA, I., WANG, Y., SCHMID, M., VORTKAMP, A. and HAAF, T. (2000) Sex-specific expression of an evolutionarily conserved male regulatory gene, DMRT1, in birds. Cytogenet Cell Genet 89: 252-257.

SMEDS, L., WARMUTH, V., BOLIVAR, P., UEBBING, S., BURRI, R., SUH, A., NATER, A., BURES, S., GARAMSZEGI, L.Z., HOGNER, S. et al., (2015). Evolutionary analysis of the female-specific avian W chromosome. Nat Commun 6: 7330.

SMITH, C.A., ANDREWS, J.E. and SINCLAIR, A.H. (1997). Gonadal sex differentiation in chicken embryos: expression of estrogen receptor and aromatase genes. J Steroid Biochem Mol Biol 60: 295-302.

SMITH, C.A., KATZ, M. and SINCLAIR, A.H. (2003). DMRT1 is upregulated in the gonads during female-to-male sex reversal in ZW chicken embryos. Biol. Reprod. 68: $560-570$

SMITH, C.A., MCCLIVE, P.J., HUDSON, Q. and SINCLAIR, A.H. (2005). Male-specific cell migration into the developing gonad is a conserved process involving PDGF signalling. Dev. Biol. 284: 337-350.

SMITH, C.A., MCCLIVE, P.J., WESTERN, P.S., REED, K.J. and SINCLAIR, A.H (1999a). Conservation of a sex-determining gene. Nature 402: 601-602.

SMITH, C.A., ROESZLER, K.N., BOWLES, J., KOOPMAN, P. and SINCLAIR, A.H. (2008a). Onset of meiosis in the chicken embryo; evidence of a role for retinoic acid. BMC Dev Biol 8: 85.

SMITH, C.A., ROESZLER, K.N., OHNESORG, T., CUMMINS, D.M., FARLIE, P.G., DORAN, T.J. and SINCLAIR, A.H. (2009a). The avian Z-linked gene DMRT1 is required for male sex determination in the chicken. Nature 461: 267-271.

SMITH, C.A., ROESZLER, K.N. and SINCLAIR, A.H. (2009b). Genetic evidence against a role for $W$-linked histidine triad nucleotide binding protein (HINTW) in avian sex determination. Int J Dev Biol 53: 59-67.

SMITH, C.A., SHOEMAKER, C.M., ROESZLER, K.N., QUEEN, J., CREWS, D. and SINCLAIR, A.H. (2008b). Cloning and expression of R-Spondin1 in different vertebrates suggests a conserved role in ovarian development. BMC Dev Biol 8: 72.

SMITH, C.A., SMITH, M.J. and SINCLAIR, A.H. (1999b). Expression of chicken steroidogenic factor-1 during gonadal sex differentiation. Gen Comp Endocrinol 113: 187-196.

SMITH, C.A., SMITH, M.J. and SINCLAIR, A.H. (1999c). Gene expression during gonadogenesis in the chicken embryo. Gene 234: 395-402.

STORCHOVA, R. and DIVINA, P. (2006). Nonrandom representation of sex-biased genes on chicken Z chromosome. J Mol Evol 63: 676-681.

SUN, W., CAI, H., ZHANG, G., ZHANG, H., BAO, H., WANG, L., YE, J., QIAN, G. and GE, C. (2017). Dmrt1 is required for primary male sexual differentiation in Chinese soft-shelled turtle Pelodiscus sinensis. Sci Rep 7: 4433.

TERANISHI, M., SHIMADA, Y., HORI, T., NAKABAYASHI, O., KIKUCHI, T., MACLEOD, T., PYM, R., SHELDON, B., SOLOVEI, I., MACGREGOR, H. et al., (2001). Transcripts of the MHM region on the chicken $Z$ chromosome accumulate as non-coding RNA in the nucleus of female cells adjacent to the DMRT1 locus. Chromosome Res 9: 147-165.

TOMASELLI, S., MEGIORNI, F., DE BERNARDO, C., FELICI, A., MARROCCO, G., MAGGIULLI, G., GRAMMATICO, B., REMOTTI, D., SACCUCCI, P., VALENTINI, 
F. et al. (2008). Syndromic true hermaphroditism due to an R-spondin1 (RSPO1) homozygous mutation. Hum Mutat 29: 220-226.

UKESHIMA, A. (1996). Germ cell death in the degenerating right ovary of the chick embryo. Zoolog Sci 13: 559-563.

URADE, Y. and HAYAISHI, O. (2000). Biochemical, structural, genetic, physiologi$\mathrm{cal}$, and pathophysiological features of lipocalin-type prostaglandin $\mathrm{D}$ synthase. Biochim Biophys Acta 1482: 259-271.

VAILLANT, S., DORIZZI, M., PIEAU, C. and RICHARD-MERCIER, N. (2001). Sex reversal and aromatase in chicken. $J$ Exp Zool 290: 727-740.

VAINIO, S., HEIKKILA, M., KISPERT, A., CHIN, N. and MCMAHON, A.P. (1999). Female development in mammals is regulated by Wnt-4 signalling. Nature 397: 405-409.

VEITIA, R., NUNES, M., BRAUNER, R., DOCO-FENZY, M., JOANNY-FLINOIS, O., JAUBERT, F., LORTAT-JACOB, S., FELLOUS, M. and MCELREAVEY, K. (1997), Deletions of distal $9 p$ associated with $46, X Y$ male to female sex reversal: definition of the breakpoints at 9p23.3-p24.1. Genomics 41: 271-274.

VERON, N., QU, Z., KIPEN, P.A., HIRST, C.E. and MARCELLE, C. (2015). CRISPR mediated somatic cell genome engineering in the chicken. Dev. Biol. 407: 68-74.

VIDAL, V.P., CHABOISSIER, M.C., DE ROOIJ, D.G. and SCHEDL, A. (2001). Sox9 induces testis development in XX transgenic mice. Nat Genet 28: 216-217.

VIGER, R.S., MERTINEIT, C., TRASLER, J.M. and NEMER, M. (1998). Transcription factor GATA-4 is expressed in a sexually dimorphic pattern during mouse gonadal development and is a potent activator of the Mullerian inhibiting substance promoter. Development 125: 2665-2675.

WADE, J. and ARNOLD, A.P. (1996). Functional testicular tissue does not masculinize development of the zebrafinch song system. Proc NatlAcad SciUSA 93: 5264-5268.

WADE, J., GONG, A. and ARNOLD, A.P. (1997). Effects of embryonic estrogen on differentiation of the gonads and secondary sexual characteristics of male zebra finches. J Exp Zool 278: 405-411.

WADE, J., SPRINGER, M.L., WINGFIELD, J.C. and ARNOLD, A.P. (1996). Neither testicular androgens nor embryonic aromatase activity alters morphology of the neural song system in zebra finches. Biol. Reprod. 55: 1126-1132.

WAJIMA, Y., FURUSAWA, T., KAWAUCHI, S., WAKABAYASHI, N., NAKABAYASHI, O., NISHIMORI, K. and MIZUNO, S. (1999). The cDNA cloning and transient expression of an ovary-specific 17beta-hydroxysteroid dehydrogenase of chickens. Gene 233: 75-82.

WANG, D., KOBAYASHI, T., ZHOU, L. and NAGAHAMA, Y. (2004). Molecular cloning and gene expression of Foxl2 in the Nile tilapia, Oreochromis niloticus. Biochem Biophys Res Commun 320: 83-89.

WANG, Q., MANK, J.E., LI, J., YANG, N. and QU, L. (2017). Allele-Specific Expression Analysis Does Not Support Sex Chromosome Inactivation on the Chicken Z Chromosome. Genome Biol Evol 9: 619-626.

WARREN, W.C., HILLIER, L.W., TOMLINSON, C., MINX, P., KREMITZKI, M., GRAVES, T., MARKOVIC, C., BOUK, N., PRUITT, K.D., THIBAUD-NISSEN, F. et al., (2017). A New Chicken Genome Assembly Provides Insight into Avian Genome Structure. G3 (Bethesda) 7: 109-117.

WARTENBERG, H., LENZ, E. and SCHWEIKERT, H.U. (1992). Sexual differentiation and the germ cell in sex reversed gonads after aromatase inhibition in the chicken embryo. Andrologia 24: 1-6.
WEBSTER, K.A., SCHACH, U., ORDAZ, A., STEINFELD, J.S., DRAPER, B.W. and SIEGFRIED, K.R. (2017). Dmrt1 is necessary for male sexual development in zebrafish. Dev. Biol. 422: 33-46.

WEI, Q., YOKOTA, C., SEMENOV, M.V., DOBLE, B., WOODGETT, J. and HE, X. (2007) R-spondin1 is a high affinity ligand for LRP6 and induces LRP6 phosphorylation and beta-catenin signaling. J Biol Chem 282: 15903-15911.

WILHELM, D., HIRAMATSU, R., MIZUSAKI, H., WIDJAJA, L., COMBES, A.N., KANAI, Y. and KOOPMAN, P. (2007). SOX9 regulates prostaglandin D synthase gene transcription in vivo to ensure testis development. J Biol Chem 282: 10553-10560.

WILHELM, D., MARTINSON, F., BRADFORD, S., WILSON, M.J., COMBES, A.N., BEVERDAM, A., BOWLES, J., MIZUSAKI, H. and KOOPMAN, P. (2005). Sertoli cell differentiation is induced both cell-autonomously and through prostaglandin signaling during mammalian sex determination. Dev. Biol. 287: 111-124.

WOODCOCK, M.E., IDOKO-AKOH, A. and MCGREW, M.J. (2017). Gene editing in birds takes flight. Mamm Genome 28: 315-323.

WRIGHT, A.E., MOGHADAM, H.K. and MANK, J.E. (2012). Trade-off between selection for dosage compensation and masculinization on the avian $Z$ chromosome. Genetics 192: 1433-1445.

WRIGHT, A.E., ZIMMER, F., HARRISON, P.W. and MANK, J.E. (2015). Conservation of Regional Variation in Sex-Specific Sex Chromosome Regulation. Genetics 201: 587-598.

YANG, X., DENG, J., ZHENG, J., XIA, L., YANG, Z., QU, L., CHEN, S., XU, G., JIANG H., CLINTON, M. et al., (2016). A Window of MHM Demethylation Correlates with Key Events in Gonadal Differentiation in the Chicken. Sex Dev 10: 152-158.

YANG, X., ZHENG, J., QU, L., CHEN, S., LI, J., XU, G. and YANG, N. (2011). Methylation status of CMHM and expression of sex-specific genes in adult sex-reversed female chickens. Sex Dev 5: 147-154.

YANG, X., ZHENG, J., XU, G., QU, L., CHEN, S., LI, J. and YANG, N. (2010). Exogenous CMHM regulates the expression of DMRT1 and ER alpha in avian testes. Mol Biol Rep 37: 1841-1847.

YOSHIMOTO, S., IKEDA, N., IZUTSU, Y., SHIBA, T., TAKAMATSU, N. and ITO, M. (2010). Opposite roles of DMRT1 and its W-linked paralogue, DM-W, in sexual dimorphism of Xenopus laevis: implications of a ZZ/ZW-type sex-determining system. Development 137: 2519-2526.

YOSHIMOTO, S., OKADA, E., UMEMOTO, H., TAMURA, K., UNO, Y., NISHIDAUMEHARA, C., MATSUDA, Y., TAKAMATSU, N., SHIBA, T. and ITO, M. (2008) A W-linked DM-domain gene, DM-W, participates in primary ovary development in Xenopus laevis. Proc Natl Acad Sci USA 105: 2469-2474.

ZHANG, S.O., MATHUR, S., HATTEM, G., TASSY, O. and POURQUIE, O. (2010). Sex-dimorphic gene expression and ineffective dosage compensation of $Z$-linked genes in gastrulating chicken embryos. BMC Genomics 11: 13.

ZHAO, D., MCBRIDE, D., NANDI, S., MCQUEEN, H.A., MCGREW, M.J., HOCKING, P.M., LEWIS, P.D., SANG, H.M. and CLINTON, M. (2010). Somatic sex identity is cell autonomous in the chicken. Nature 464: 237-242.

ZIMMER, F., HARRISON, P.W., DESSIMOZ, C. and MANK, J.E. (2016). Compensation of Dosage-Sensitive Genes on the Chicken Z Chromosome. Genome Biol Evol 8: 1233-1242. 


\section{Further Related Reading, published previously in the Int. J. Dev. Biol.}

Sexual dimorphism of AMH, DMRT1 and RSPO1 localization in the developing gonads of six anuran species

Rafal P. Piprek, Anna Pecio, Katarzyna Laskowska-Kaszub,Jacek Z. Kubiak and Jacek M. Szymura

Int. J. Dev. Biol. (2013) 57: 891-895

https://doi.org/10.1387/ijdb.130192rp

Regulation of germ cell meiosis in the fetal ovary

Cassy M. Spiller, Josephine Bowles and Peter Koopman

Int. J. Dev. Biol. (2012) 56: 779-787

https://doi.org/10.1387/ijdb.120142pk

Molecular and cellular machinery of gonadal differentiation in mammals

Rafal P. Piprek

Int. J. Dev. Biol. (2010) 54: 779-786

https://doi.org/10.1387/ijdb.092939rp

In vitro germ cell differentiation during sex differentiation in a teleost fish

Tohru Kobayashi

Int. J. Dev. Biol. (2010) 54: 105-111

https://doi.org/10.1387/ijdb.082836tk

The spatio-temporal pattern of testis organogenesis in mammals - insights from the mole Francisco D. Carmona, Darío G. Lupiáñez, José-Ezequiel Martín, Miguel Burgos, Rafael Jiménez and Federico Zurita

Int. J. Dev. Biol. (2009) 53: 1035-1044

https://doi.org/10.1387/ijdb.072470fc

Foetal germ cells: striking the balance between pluripotency and differentiation Patrick Western

Int. J. Dev. Biol. (2009) 53: 393-409

https://doi.org/10.1387/ijdb.082671pw

Germ cells, gonads and sex reversal in marsupials

M B Renfree and G Shaw

Int. J. Dev. Biol. (2001) 45: 557-567

http://www.intjdevbiol.com/web/paper/11417899

5 yr ISI Impact Factor $(2016)=2.421$
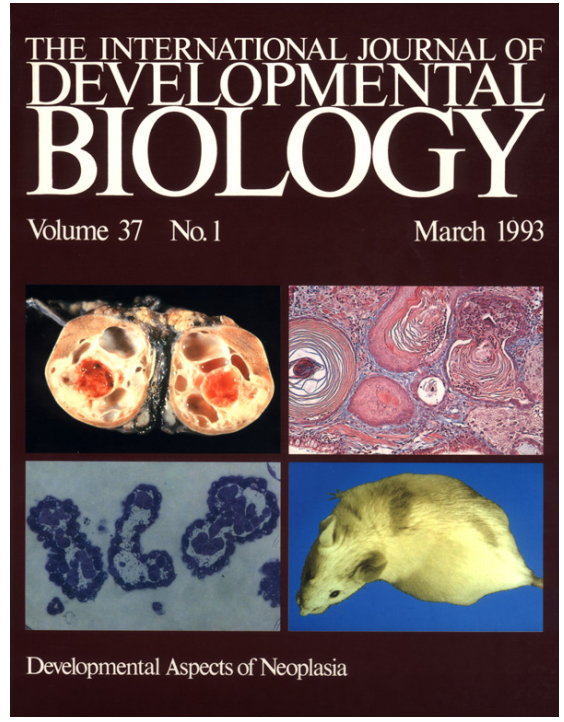

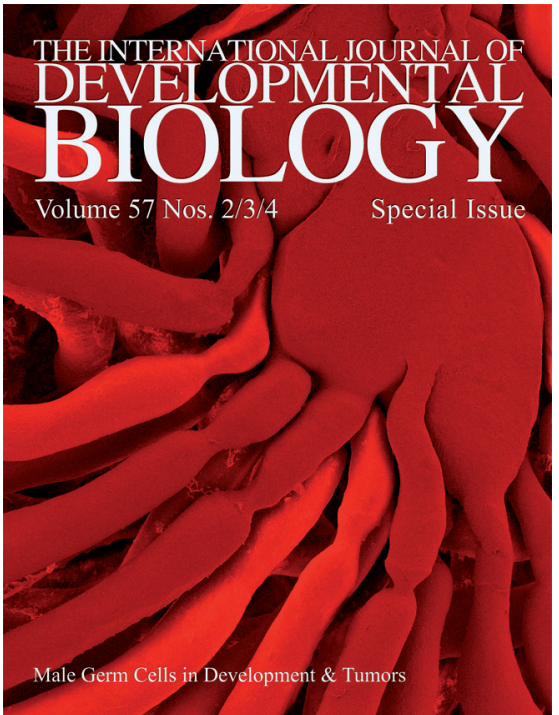

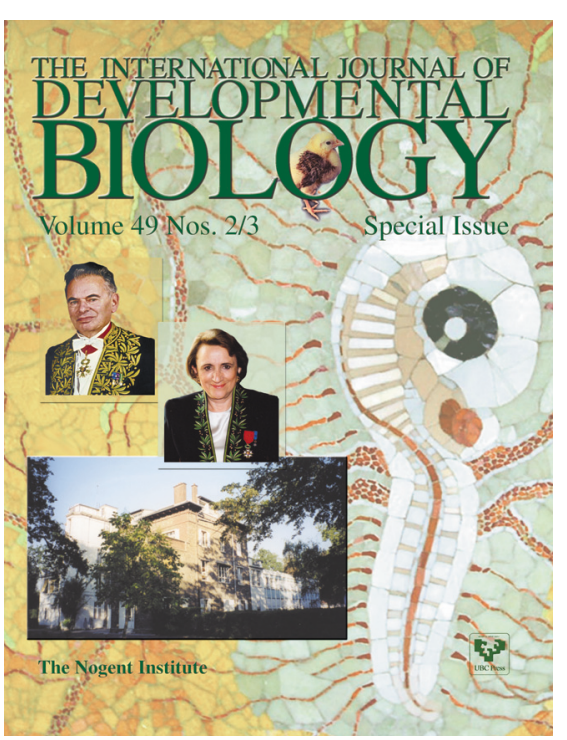

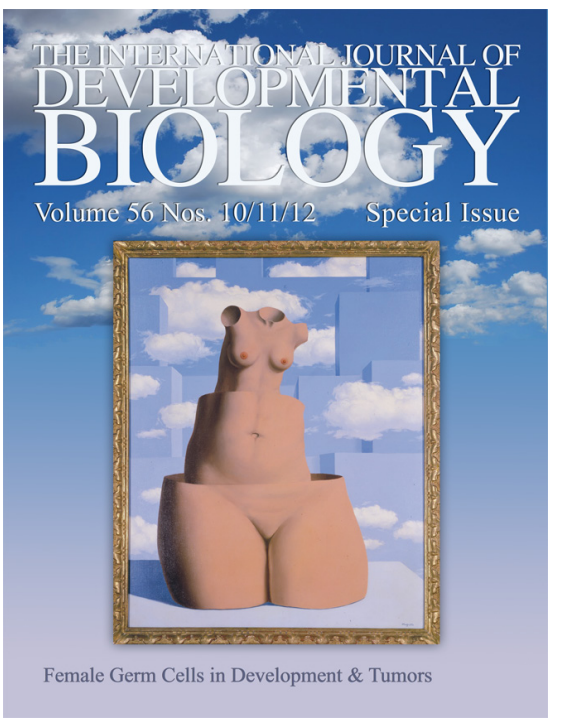

